Article

\title{
Entomopathogenic Filamentous Fungi as Biocatalysts in Glycosylation of Methylflavonoids
}

\author{
Agnieszka Krawczyk-Łebek *(D), Monika Dymarska ${ }^{\circledR}$, Tomasz Janeczko $₫$ and \\ Edyta Kostrzewa-Susłow * \\ Department of Chemistry, Faculty of Biotechnology and Food Science, Wrocław University of Environmental \\ and Life Sciences, 50-375 Wrocław, Poland; monika.dymarska@upwr.edu.pl (M.D.); \\ tomasz.janeczko@upwr.edu.pl (T.J.) \\ * Correspondence: agnieszka.krawczyk-lebek@upwr.edu.pl (A.K.-Ł.); edyta.kostrzewa-suslow@upwr.edu.pl (E.K.-S.)
}

Received: 5 September 2020; Accepted: 30 September 2020; Published: 4 October 2020

\begin{abstract}
Flavonoids are known for their numerous biological activities; however, their pharmacological application is limited by poor bioavailability. Glycosides are usually more stable and more soluble in water and in this form, flavonoids are present in nature. Likewise, the presence of the methyl group in the flavonoid skeleton results in facilitated absorption and greater bioavailability. Entomopathogenic filamentous fungi are effective in the biotransformation of flavonoids; they are known especially for efficient glycosylation. In the current study we used strains of Beauveria bassiana $\mathrm{KCH} \mathrm{J} 1.5$ and Isaria fumosorosea $\mathrm{KCH} \mathrm{J2}$ to biotransform flavonoids with a single methyl group. 2'-Hydroxy-5'-methylchalcone was biotransformed by both strains into 2'-hydroxy-5'-methylchalcone $3-\mathrm{O}-\beta$-D-( $4^{\prime \prime}-\mathrm{O}$-methyl)-glucopyranoside. In the culture of B. bassiana $\mathrm{KCHJ} 1.5$ four products were obtained from 6-methylflavanone: 4'-hydroxy-6-methylflavanone 3'-O- $\beta$-D-(4"'-O-methyl)-glucopyranoside; $4^{\prime}$-hydroxyflavanone 6-methylene-O- $\beta$-D-(4" $-O$-methyl)-glucopyranoside; 6-hydroxymethylflavanone $3^{\prime}-O-\beta$-D-(4" $-O$-methyl)-glucopyranoside and $4^{\prime}$-hydroxy-6-hydroxymethylflavanone $3{ }^{\prime}-O-\beta$-D- $\left(4^{\prime \prime}-\right.$ $\mathrm{O}$-methyl) -glucopyranoside. Biotransformation with I. fumosorosea $\mathrm{KCH} \mathrm{J} 2$ as a biocatalyst resulted in the formation of 6-methylflavanone $4^{\prime}-O-\beta$-D-( $4^{\prime \prime}-O$-methyl)-glucopyranoside and 2-phenyl-6methylchromane $4-O-\beta$-D-(4"-O-methyl)-glucopyranoside. All of these flavonoids can be used in biological activity tests and can be useful in studies concerning structure-bioactivity relationships.
\end{abstract}

Keywords: flavonoids; biotransformations; glycosylation; methylchalcone; methylflavanone; O-methylglucosides; Beauveria bassiana; Isaria fumosorosea

\section{Introduction}

Flavonoid compounds are plant secondary metabolites engaged in various plants' interactions with the environment [1]. They are able to exert a wide range of biological activities: antioxidant, anti-inflammatory, antiallergic, antimicrobial, antiplatelet, anticancer and neuroprotective [1-3]. Their occurrence in a plant based diet is ubiquitous [4]. However, pharmacological application of flavonoid aglycons is limited by their poor bioavailability [5,6]. In nature, flavonoid derivatives-products of glycosylation, methylation, prenylation, acetylation and polymerization - are very common [7] and the most abundant are glucosides. Addition of sugar moiety (or moieties) to flavonoid aglycone is catalyzed by uridine diphosphate (UDP) glycosyltransferases (UGTs) [8,9]. Flavonoids glycosylation results in the modulation of their physicochemical and biological properties, most of all by improving their aqueous solubility and facilitating their intracellular and intercellular transportation. Nonetheless, the impact of the glycosylation on the biological properties of flavonoids is complicated, because it depends on the structure of the flavonoid core, the position of the sugar attachment and the number of sugar moieties [10-16]. 
Many flavonoid glycosides with potential biological activity occur in plants in small amounts and therefore their extraction is difficult. Chemical synthesis is inefficient in the production of flavonoid glycosides, because of laborious procedures necessary to achieve regio- and stereo-selectivity, and low isolated yields due to drastic reaction conditions resulting in the decomposition of aglycones. However, flavonoid glycosides, both well-known and novel, can be obtained by microbial glycosylation of already existing flavonoid aglycons. Enzymatic glycosylation allows to overcome these obstacles. It can be carried out by a few different methods: whole-cell biotransformation, in vivo total biosynthesis and in vitro enzymatic reaction [11,12,17-20]. Among these methods biotransformation is promising, because it offers an eco-friendly, one-pot and one-step process [21].

Methylation at the ring position of flavonoids leads to derivatives with increased metabolic stability due to insusceptibility to glucuronic acid or sulfate conjugation. Methylation also leads to greatly improved intestinal absorption, and bioavailability $[1,7,22]$. Methylated flavonoids are widely present in plants, but still less abundant than unmethylated flavonoid aglycons and flavonoid glycosides. Among two types of methylation in flavonoids, $O$-methylation and $C$-methylation, the second one is less common and has been found in limited plant species, such as Cleistocalyx operculatus [23-25], Picea neoveitchii [26], Corymbia torelliana [27,28] and Campomanesia xanthocarpa [29], and occurs especially at C-6 of the flavonoid skeleton.

There is some evidence of biological activity of $C$-methylated flavonoids isolated from plants. From the twigs and leaves of $P$. neoveitchii Mast, two $C$-methylated flavonoids were isolated: 5,7-dihydroxy-3-methoxy-6-methylflavone 8,4'-di-O- $\beta$-D-glucopyranoside and 4',5,7,8-tetrahydroxy3-methoxy-6-methylflavone 8-O- $\beta$-D-glucopyranoside. The first one exhibited moderate antifungal activity against several plant pathogens (Pyricularia grisea (Cooke) Sacc., Sclerotium rocfsii Sacc. and Alternaria mali Roberts). The second one showed a significant inhibitory effect against $S$. rocfsii. Both compounds exhibited potent cytotoxicity against Spodoptera litura Fabricius [26].

Methylated chalcones from $C$. operculatus also showed biological activity. (E)-2',4,4'-Trihydroxy6'-methoxy-3', 5'-dimethylchalcone, 2' , 4'-dihydroxy-6'-methoxy-3', $5^{\prime}$ - dimethylchalcone, 2' $4^{\prime}$ '-dihydroxy$3^{\prime}$-methyl-6'-methoxychalcone and 2,2', $4^{\prime}$-trihydroxy-6'-methoxy- $3^{\prime}, 5^{\prime}$-dimethylchalcone displayed notable inhibitory activity on the viral neuraminidases from two influenza viral strains, H1N1 and H9N2. The first one exhibited strong inhibition against the neuraminidases from novel influenza H1N1 (WT) and oseltamivir-resistant novel H1N1 (H274Y mutant) expressed in 293T cells. Kinetic studies have indicated that tested chalcones acted as noncompetitive inhibitors to neuraminidases which are responsible for enabling viruses to leave infected cells by decomposition of their cell membranes [25].

In studies conducted on oocytes of Xenopus laevis with expressed human recombinant $\mathrm{GABA}_{\mathrm{A}}$ receptors 6-methylflavanone acted as a positive allosteric modulator. $\mathrm{GABA}_{\mathrm{A}}$ receptors are the main inhibitory neurotransmitters in the central nervous system and are classified under six subfamilies of protein subunits: $\alpha, \beta, \gamma, \delta, \varepsilon$ and $\theta$. Anxiolysis and sedation are considered to be mediated via $\mathrm{GABA}_{\mathrm{A}}$ receptors ( $\alpha_{2}$ and $\alpha_{1}$, respectively). The tested compound was much more effective at $\alpha_{2} \beta_{2} \gamma_{2 L}$ than at $\alpha_{1} \beta_{2} \gamma_{2 L}$ and $\alpha_{1} \beta_{2}$ GABA $_{A}$ receptors. This may be quite a unique type of selectivity, significant in seeking new targeted drugs, acting as $\mathrm{GABA}_{\mathrm{A}}$ receptors agonists and producing certain sedative effects without the unwanted side effects of benzodiazepines [30].

B. bassiana is an entomopathogenic filamentous fungi that affects a broad range of arthropods. It has been used as a biological control agent of various arthropod pests for many years [31-33]. The pathogenesis and virulence of Beauveria isolates is connected with the production of toxicogenic metabolites, antioxidant enzymes and primarily extracellular cuticle-degrading enzymes such as chitinases, lipases, and proteases [33,34]. Since B. bassiana genome sequence is already known [35] there is a lot of interest in recognition of genes involved in its pathogenesis and virulence [32,36]. Enzymatic systems of $B$. bassiana, that are responsible for a cuticle-degradation are also applied to the biotransformations. B. bassiana has the ability to transform a broad range of substrates such as cyclic and aliphatic ketones, flavonoids and steroids [37]. This fungus is capable of performing reactions such as hydroxylation, glycosylation or deglycosylation, acetylation and reduction [37]. Most of the 
enzymes responsible for these reactions have not been described until now [37]. Likewise I. fumosorosea serves as a biological control agent and alternative to chemical pesticides [38]. Its secondary metabolites exhibit a great variety of biological activities [39]. This genus was used as a biocatalyst by our team in previous studies of flavonoid biotransformations [12-15].

The current studies are a continuation of our previous work with 6-methylflavone as the biotransformation substrate [12]. In the present study we synthesized two flavonoid compounds with methyl group at C-6 of flavanone skeleton (C-5' in the case of chalcone) and afterwards biotransformed them with entomopathogenic filamentous fungi strains of B. bassiana $\mathrm{KCH} \mathrm{J1.5} \mathrm{and} \mathrm{I.} \mathrm{fumosorosea}$ $\mathrm{KCH} \mathrm{J2}$ as biocatalysts. As a result of $2^{\prime}$-hydroxy-5'-methylchalcone biotransformation in both cultures one main product $2^{\prime}$-hydroxy- $5^{\prime}$-methylchalcone 3-O- $\beta$-D- $\left(4^{\prime \prime}-O-\right.$-methyl $)$-glucopyranoside was obtained. 6-Methylflavanone was efficiently biotransformed by both used biocatalysts. Each strain formed different biotransformation products. Six flavanones $4^{\prime \prime}$-O-methylglucopyranosides were obtained. All biotransformation products have not been previously described in the scientific literature. The biotransformation products may be utilized in further studies as potentially biologically active compounds and can be useful in investigations concerning structure-bioactivity relationships.

\section{Results and Discussion}

The following results are a continuation of studies focused on biotransformations of flavonoid compounds with a methyl group at C-6 in cultures of entomopathogenic filamentous fungi. In the previous paper about biotransformation of 6-methylflavone by the strain I. fumosorosea $\mathrm{KCH} \mathrm{J2,} \mathrm{two} \mathrm{new}$ products were obtained: 6-methylflavone $8-O-\beta-\mathrm{D}-\left(4^{\prime \prime}-\mathrm{O}\right.$-methyl)-glucopyranoside $(6.6 \%$ yield $)$ and 6-methylflavone $4^{\prime}-O-\beta$-D-(4" $-O$-methyl)-glucopyranoside (13.2\% yield) [12].

In the present paper two flavonoid substrates (chalcone and flavanone), that are analogs of the 6-methylflavone, were utilized. Two strains of the enthompathogenic filamentous fungi I. fumosorosea $\mathrm{KCH} \mathrm{J} 2$ and B. bassiana $\mathrm{KCH} \mathrm{J1.5,} \mathrm{isolated} \mathrm{from} \mathrm{the} \mathrm{environment} \mathrm{and} \mathrm{characterized} \mathrm{previously} \mathrm{[12,37]}$ were used as biocatalysts. Experiments performed in a semi-preparative scale enabled us to determine the chemical structures of biotransformation products and their isolated yields unambiguously. Hereby, seven biotransformation products that have not yet been described in the scientific literature were obtained: $2^{\prime}$-hydroxy-5'-methylchalcone 3-O- $\beta$-D-( $4^{\prime \prime}-O$-methyl)-glucopyranoside (3a), $4^{\prime}$-hydroxy-6-methylflavanone 3'-O- $\beta$-D-(4'"-O-methyl)-glucopyranoside (4a), $4^{\prime}$-hydroxyflavanone 6-methylene-O- $\beta$-D-( $4^{\prime \prime}-O$-methyl)-glucopyranoside (4b), 6-hydroxymethylflavanone $3^{\prime}-O-\beta$-D(4' -O-methyl)-glucopyranoside (4c), 4'-hydroxy-6-hydroxymethylflavanone 3'-O- $\beta$-D-(4"'-O-methyl)glucopyranoside (4d), 6-methylflavanone $4^{\prime}-O-\beta$-D-(4' $-O$-methyl)-glucopyranoside (4e) and 2-phenyl6-methylchromane 4-O- $\beta$-D-(4"'-O-methyl)-glucopyranoside (4f).

The substrates for biotransformation were obtained by a two-step synthesis (Scheme 1).

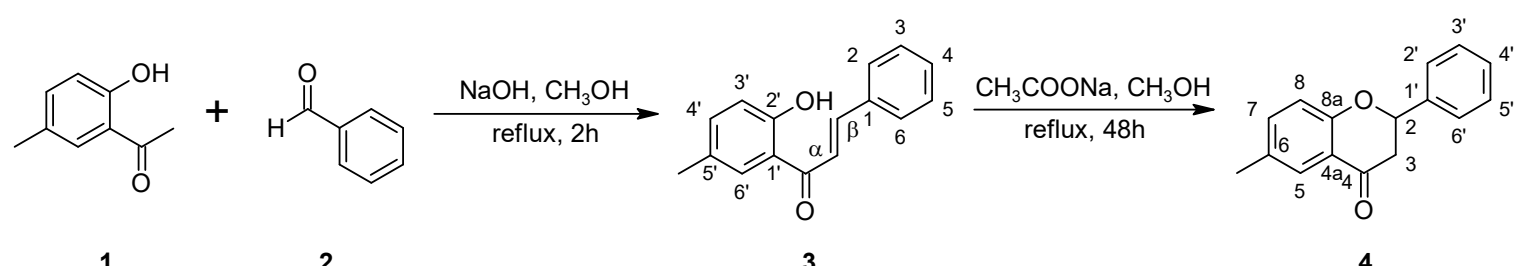

Scheme 1. Synthesis of 2'-hydroxy-5'-methylchalcone (3) and 6-methylflavanone (4).

\subsection{Biotransformations of 2'-hydroxy-5'-methylchalcone (3)}

In the experiment $2^{\prime}$-hydroxy-5'-methylchalcone (3) was synthesized in a Claisen-Schmidt condensation reaction between $2^{\prime}$-hydroxy-5'-methylacetophenone (1) and benzaldehyde (2) with a $50.1 \%$ yield. As a result of its 10-day biotransformation, in the B. bassiana $\mathrm{KCH} \mathrm{J1.5} \mathrm{culture} \mathrm{one} \mathrm{main}$ product $2^{\prime}$-hydroxy-5'-methylchalcone 3-O- $\beta$-D-(4'-O-methyl)-glucopyranoside (3a) with a $29.5 \%$ yield (Scheme 2) was isolated and purified by means of the preparative Thin Layer Chromatography 
(TLC) method with chloroform and methanol $(9: 1 v / v)$ as eluents. The same product was obtained using I. fumosorosea $\mathrm{KCH} \mathrm{J2}$ as a biocatalyst.

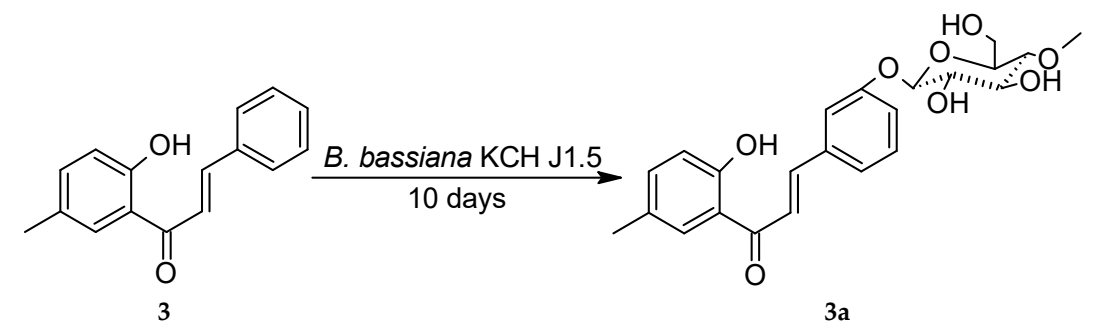

Scheme 2. Microbial transformation of 2'-hydroxy-5'-methylchalcone (3) in B. bassiana KCH J1.5 culture.

The product 3a was analyzed by NMR spectroscopy that allowed to establish its chemical structure (Tables 1 and 2, Scheme 3).

The presence of a glucose unit in the compound 3a was confirmed by five characteristic carbon signals observed in the region from $\delta=80.5 \mathrm{ppm}$ to $\delta=62.3 \mathrm{ppm}$ in the Carbon-13 Nuclear Magnetic Resonance $\left({ }^{13} \mathrm{C}-\mathrm{NMR}\right)$ spectrum, as well as proton signals of $\delta \mathrm{H}$ ranging from $\delta=3.92 \mathrm{ppm}$ to $\delta=3.19 \mathrm{ppm}$ in the Proton Nuclear Magnetic Resonance ( $\left.{ }^{1} \mathrm{H}-\mathrm{NMR}\right)$ spectrum. Moreover, the attachment of a sugar unit to substrate 3 was confirmed by a one-proton doublet from the proton at the anomeric carbon atom at $\delta=5.03 \mathrm{ppm}$ in the ${ }^{1} \mathrm{H}$-NMR spectrum. The $\beta$-configuration of the glucose unit was proved by the coupling constant $(J=7.8 \mathrm{~Hz})$ for the anomeric proton. A three-proton singlet at $\delta=3.57 \mathrm{ppm}$ in the ${ }^{1} \mathrm{H}-\mathrm{NMR}$ spectrum and the corresponding signal at $\delta=60.6 \mathrm{ppm}$ in the ${ }^{13} \mathrm{C}$-NMR spectrum evidences that one of the hydroxyl groups of sugar unit has been methylated. $O$-methylation occurred in the $\mathrm{C}-4^{\prime \prime}$ hydroxyl group of the glucose unit. It was detected in the Heteronuclear Multiple Bond Coherence (HMBC) spectrum, where the proton signal due to $-\mathrm{OCH}_{3}$ was correlated with the signal of $\mathrm{C}-4^{\prime \prime}$ (about $\delta=80 \mathrm{ppm}$ ) in the glucose unit. Sugar moiety was attached to $\mathrm{C}-3$, because in the HMBC spectrum signal due to the proton at hemiacetal carbon atom $(\delta=5.03 \mathrm{ppm})$ was correlated with the $C-3$ signal $(\delta=159.2 \mathrm{ppm})$, which was shifted from $\delta=129.2 \mathrm{ppm}$, indicating the attachment of an electronegative atom. Additionally, protons in the ${ }^{1} \mathrm{H}-\mathrm{NMR}$ spectrum at C-2 and C- 6 became non-equivalent, and the proton at C-3 disappeared. Shifted signals can be observed: one multiplet from the proton at $C-2(\delta=7.61 \mathrm{ppm})$, which became isolated in the correlation spectrum, one doublet of doublets of doublets from the proton at C-4 $(\delta=7.16 \mathrm{ppm})$ and one doublet from the proton at $C-6(\delta=7.47 \mathrm{ppm})$. Signal from proton at $C-5$ was slightly shifted and merged with signal from the proton at $\mathrm{C}-4^{\prime}$. Signals from one proton of the hydroxyl group at $\mathrm{C}-2^{\prime}$ and three protons of the methyl group at C-5 remained intact.

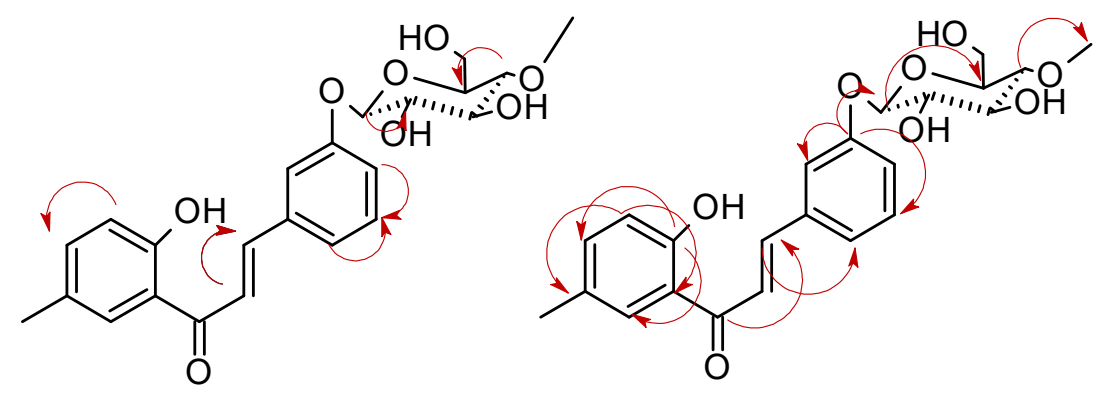

Scheme 3. Key Correlation Spectroscopy (COSY), (on the left) and HMBC (on the right) correlations for the structure elucidation of product $3 \mathbf{a}$. 
Table 1. ${ }^{1} \mathrm{H}$-NMR chemical shifts $\delta$ (ppm) and coupling constants $J(\mathrm{~Hz})$ of 2 '-hydroxy-5' - methylchalcone (3) in Chloroform-d, and product of its biotransformation 3a in Acetone-d6, $600 \mathrm{MHz}$ (Supplementary Materials).

\begin{tabular}{|c|c|c|}
\hline \multirow{2}{*}{ Proton } & \multicolumn{2}{|c|}{ Compound } \\
\hline & 3 & $3 a$ \\
\hline $\mathrm{H}-2$ & $7.68(\mathrm{~m})$ & $7.61(\mathrm{~m})$ \\
\hline H-3 & $\begin{array}{c}7.45(\mathrm{dd}) \\
J=4.8,1.8\end{array}$ & - \\
\hline $\mathrm{H}-4$ & $\begin{array}{c}7.45(\mathrm{dd}) \\
J=4.8,1.8\end{array}$ & $\begin{array}{c}7.16(\mathrm{ddd}) \\
J=8.1,2.3,0.6\end{array}$ \\
\hline H-5 & $\begin{array}{c}7.45(\mathrm{dd}) \\
J=4.8,1.8\end{array}$ & $\begin{array}{c}7.40(\mathrm{dd}) \\
J=13.0,5.0\end{array}$ \\
\hline H-6 & $7.68(\mathrm{~m})$ & $\begin{array}{l}7.47(\mathrm{~d}) \\
J=7.7\end{array}$ \\
\hline$H-\alpha$ & $7.68(\mathrm{~m})$ & $\begin{array}{c}8.03(\mathrm{~d}) \\
J_{\alpha, \beta}=15.5\end{array}$ \\
\hline$H-\beta$ & $\begin{array}{c}7.92(\mathrm{~d}) \\
J_{\beta, \alpha}=15.5\end{array}$ & $\begin{array}{c}7.87(\mathrm{~d}) \\
J_{\beta, \alpha}=15.5\end{array}$ \\
\hline H-2' & - & - \\
\hline $\mathrm{H}-3^{\prime}$ & $\begin{array}{l}6.94(\mathrm{~d}) \\
J=8.4\end{array}$ & $\begin{array}{l}6.89(\mathrm{~d}) \\
J=8.4\end{array}$ \\
\hline $\mathrm{H}-4^{\prime}$ & $\begin{array}{c}7.32(\mathrm{dd}) \\
J=8.4,2.1\end{array}$ & $\begin{array}{c}7.40(\mathrm{dd}) \\
J=13.0,5.0\end{array}$ \\
\hline $\mathrm{H}-5^{\prime}$ & - & - \\
\hline $\mathrm{H}-6^{\prime}$ & $7.68(\mathrm{~m})$ & $\begin{array}{l}8.12(\mathrm{~d}) \\
J=1.3\end{array}$ \\
\hline $\mathrm{H}-\mathrm{1}^{\prime \prime}$ & - & $\begin{array}{l}5.03(\mathrm{~d}) \\
J=7.8\end{array}$ \\
\hline $\mathrm{H}-2^{\prime \prime}$ & - & $\begin{array}{c}3.52(\mathrm{ddd}) \\
J=15.1,9.1,5.1\end{array}$ \\
\hline $\mathrm{H}-3^{\prime \prime}$ & - & $3.66(\mathrm{~m})$ \\
\hline $\mathrm{H}-4^{\prime \prime}$ & - & $3.19(\mathrm{~m})$ \\
\hline $\mathrm{H}-5^{\prime \prime}$ & - & $\begin{array}{c}3.61(\mathrm{ddd}) \\
J=9.7,5.8,2.2\end{array}$ \\
\hline $\mathrm{H}-6^{\prime \prime}$ & - & $\begin{array}{c}3,92(\mathrm{ddd}) \\
J=11.8,5.6,2.1 \\
3.73(\mathrm{dt}) \\
J=12.1,6.2\end{array}$ \\
\hline $\mathrm{C}^{\prime \prime \prime}-\mathrm{OCH}_{3}$ & - & $3.57(\mathrm{~s})$ \\
\hline $\mathrm{C} 2^{\prime}-\mathrm{OH}$ & $12.63(\mathrm{~s})$ & $12.67(\mathrm{~s})$ \\
\hline $\mathrm{C}^{\prime}-\mathrm{CH}_{3}$ & $2.36(\mathrm{~s})$ & $2.35(\mathrm{~s})$ \\
\hline
\end{tabular}


Table 2. ${ }^{13} \mathrm{C}-\mathrm{NMR}$ chemical shifts $\delta$ (ppm) of 2'-hydroxy-5'-methylchalcone (3) in Chloroform-d, and product of its biotransformation 3a in Acetone-d6, $151 \mathrm{MHz}$ (Supplementary Materials).

\begin{tabular}{|c|c|c|}
\hline \multirow{2}{*}{ Carbon } & \multicolumn{2}{|c|}{ Compound } \\
\hline & 3 & $3 \mathbf{a}$ \\
\hline$C-1$ & 134.8 & 137.1 \\
\hline$C-2$ & 128.8 & 116.7 \\
\hline$C-3$ & 129.2 & 159.2 \\
\hline C-4 & 131.0 & 120.2 \\
\hline$C-5$ & 129.2 & 130.8 \\
\hline C-6 & 128.8 & 124.3 \\
\hline$C-\alpha$ & 120.4 & 122.0 \\
\hline$C-\beta$ & 145.4 & 145.6 \\
\hline$C-1^{\prime}$ & 119.8 & 120.5 \\
\hline$C-2^{\prime}$ & 161.7 & 162.5 \\
\hline$C-3^{\prime}$ & 118.5 & 118.7 \\
\hline$C-4^{\prime}$ & 137.7 & 138.5 \\
\hline$C-5^{\prime}$ & 128.1 & 129.3 \\
\hline$C-6^{\prime}$ & 129.5 & 131.1 \\
\hline$C-1^{\prime \prime}$ & - & 101.7 \\
\hline$C-2^{\prime \prime}$ & - & 75.0 \\
\hline$C-3^{\prime \prime}$ & - & 78.1 \\
\hline$C-4^{\prime \prime}$ & - & 80.5 \\
\hline$C-5^{\prime \prime}$ & - & 77.2 \\
\hline$C-6^{\prime \prime}$ & - & 62.3 \\
\hline $\mathrm{C}^{\prime \prime}-\mathrm{OCH}_{3}$ & - & 60.6 \\
\hline $\mathrm{C}=\mathrm{O}$ & 193.8 & 194.9 \\
\hline $\mathrm{C}^{\prime}-\underline{\mathrm{CH}_{3}}$ & 20.8 & 20.4 \\
\hline
\end{tabular}

Glycosylation of chalcones is rarely reported. Among reported microbial transformations of the chalcones into their glycosides, there are known reactions with xanthohumol as a substrate. These biotransformations led to the production of: xanthohumol $4^{\prime}-O-\beta$-D-glucopyranoside in the cultures of Penicillium chrysogenum 6933 [40], Absidia coerulea AM93 and Rhizopus nigricans UPF701 [41], xanthohumol 4,4'-O- $\beta$-diglucopyranoside in the culture of $P$. chrysogenum 6933 [40], xanthohumol 4' $O-\beta$-D-(4"-O-methyl)-glucopyranoside in the cultures of B. bassiana AM278 [42] and B. bassiana AM446 [41], and isoxanthohumol 7-O- $\beta$-D-glucopyranoside in the cultures of Cunninghamella elegans 6992 [40] and Mortierella mutabilis AM404 [41]. Several studies with enzymes of the glycosyltransferase family led to the formation of the chalcone glycosides at three sites: $2^{\prime}, 4^{\prime}$ and less often 4 [43]. However, there is no evidence of the glycosylation at C-3 of the chalcone skeleton and also no reports of 2'-hydroxy-5'-methylchalcone (3) biotransformations.

\subsection{Biotransformations of 6-methylflavanone (4) in the culture of B. bassiana KCH J1.5}

6-Methylflavanone (4) was synthesized from 2'-hydroxy-5'-methylchalcone (3) with $62.3 \%$ yield and utilized in 10-day biotransformation in the culture of B. bassiana $\mathrm{KCH} \mathrm{J1.5.} \mathrm{Four} \mathrm{biotransformation} \mathrm{products}$ were obtained and isolated: $4^{\prime}$-hydroxy-6-methylflavanone $3^{\prime}$-O- $\beta$-D-(4"'-O-methyl)-glucopyranoside (4a) with $6.9 \%$ yield, $4^{\prime}$-hydroxyflavanone 6-methylene-O- $\beta$-D-( $4^{\prime \prime}$-O-methyl)-glucopyranoside (4b) with $7.9 \%$ 
yield, 6-hydroxymethylflavanone $3^{\prime}-O-\beta$-D-(4'-O-methyl)-glucopyranoside (4c) with $3.4 \%$ yield and $4^{\prime}$-hydroxy-6-hydroxymethylflavanone $3^{\prime}-O-\beta$-D-(4"-O-methyl)-glucopyranoside (4d) with $8.0 \%$ yield (Scheme 4).

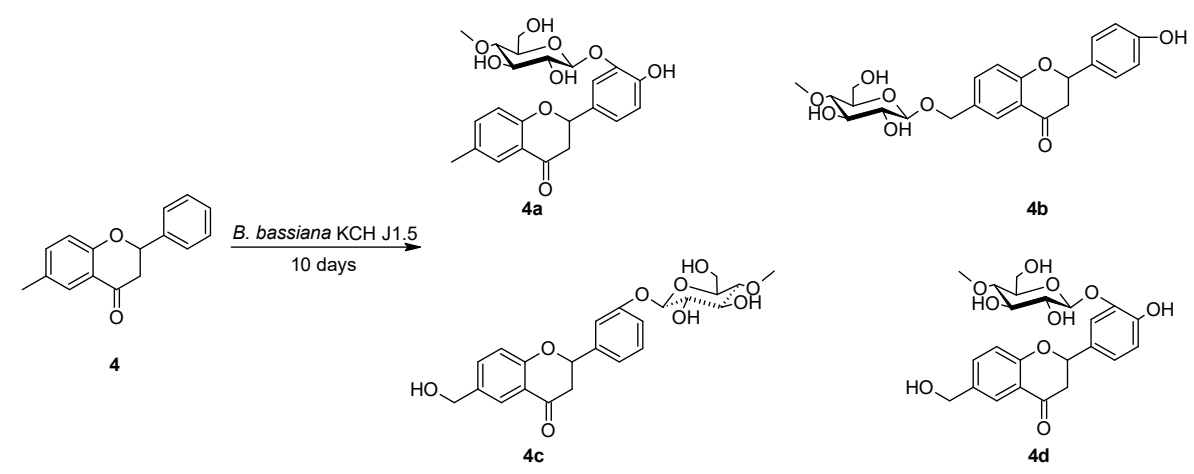

Scheme 4. Microbial transformation of 6-methylflavanone (4) in B. bassiana KCH J1.5 culture.

The products $\mathbf{4 a}-\mathbf{4} \mathbf{d}$ were analyzed by NMR spectroscopy which allowed for the establishment of their chemical structures (Tables 3 and 4, Schemes 5-8).

The presence of a glucose unit in compounds $4 \mathbf{a}-\mathbf{4 d}$ was established by five characteristic carbon signals observed in the region from about $\delta=80.0 \mathrm{ppm}$ to about $\delta=62.0 \mathrm{ppm}$ in the ${ }^{13} \mathrm{C}$-NMR spectra, as well as proton signals of $\delta \mathrm{H}$ ranging from about $\delta=3.9 \mathrm{ppm}$ to $\delta=3.1 \mathrm{ppm}$ in the ${ }^{1} \mathrm{H}-\mathrm{NMR}$ spectra. Additionally, the attachment of a sugar unit to substrate 4 was confirmed by a one-proton doublet from the proton at the anomeric carbon atom in the ${ }^{1} \mathrm{H}-\mathrm{NMR}$ spectrum of $4 \mathbf{a}$ at $\delta=4.79 \mathrm{ppm}, 4 \mathbf{b}$ at $\delta$ $=4.36 \mathrm{ppm}, 4 \mathrm{c}$ at $\delta=4.98 \mathrm{ppm}$ and $4 \mathrm{~d}$ at $\delta=4.82 \mathrm{ppm}$. The $\beta$-configuration of the glucose unit was proved by the coupling constant (about $J=7.9 \mathrm{~Hz}$ ) for the anomeric proton. A three-proton singlet at about $\delta=3.6 \mathrm{ppm}$ in the ${ }^{1} \mathrm{H}-\mathrm{NMR}$ spectra and the corresponding signal at about $\delta=60.6 \mathrm{ppm}$ in the ${ }^{13} \mathrm{C}-\mathrm{NMR}$ spectra of $\mathbf{4 a}-\mathbf{4 d}$ evidences that one of the hydroxyl groups of sugar unit has been methylated. O-methylation occurred in all products at the C-4" hydroxyl group of the glucose unit. It was detected in the $\mathrm{HMBC}$ spectra, that the proton signals due to $-\mathrm{OCH}_{3}$, were correlated with the signals of $C-4^{\prime \prime}$ (about $\delta=80 \mathrm{ppm}$ ) in the glucose units.

Based on the HMBC spectrum, a sugar moiety was attached to C- $3^{\prime}$ in the case of compound $4 a$, due to the proton at the anomeric carbon atom $(\delta=4.79 \mathrm{ppm})$ being coupled with the $\mathrm{C}-3^{\prime}$ signal $(\delta=146.1 \mathrm{ppm})$, which was shifted from $\delta=129.5 \mathrm{ppm}$, indicating the attachment of an electronegative atom. Moreover, protons in the ${ }^{1} \mathrm{H}-\mathrm{NMR}$ spectrum at $\mathrm{C}-2^{\prime}$ and $\mathrm{C}-6^{\prime}$ became non-equivalent and protons at $C-3^{\prime}$ and $C-4^{\prime}$ were not present, suggesting substitution. The $C-4^{\prime}$ signal at the ${ }^{13} \mathrm{C}-\mathrm{NMR}$ spectrum $(\delta=149.0 \mathrm{ppm})$, which was shifted from $\delta=129.3 \mathrm{ppm}$, indicates the attachment of an electronegative oxygen atom from a hydroxyl group. In the ${ }^{1} \mathrm{H}-\mathrm{NMR}$ spectrum shifted signals of flavanone ring B can be observed: one multiplet from the proton at $C-2^{\prime}(\delta=7.39 \mathrm{ppm})$, one doublet from the proton at $C-5^{\prime}(\delta=6.91 \mathrm{ppm})$, and one doublet of triplets at $C-6^{\prime}(\delta=7.16 \mathrm{ppm})$. In the COSY spectrum protons at $\mathrm{C}-5^{\prime}$ and at $\mathrm{C}-6^{\prime}$ correlate, and the proton at $\mathrm{C}-2^{\prime}$ does not couple with any proton, which also confirms substitution at $\mathrm{C}-3^{\prime}$ and $\mathrm{C}-4^{\prime}$. In the HMBC spectrum, a strong cross-peak between $\mathrm{C}-3^{\prime}$ and $\mathrm{H}-2^{\prime}$ and between $\mathrm{C}-3^{\prime}$ and $\mathrm{H}-5^{\prime}$, while no peak between $\mathrm{C}-3^{\prime}$ and $\mathrm{H}-6^{\prime}$, can be observed. At the same time a strong cross-peak between $\mathrm{C}-4^{\prime}$ and $\mathrm{H}-2^{\prime}$ (and $\mathrm{H}-5^{\prime}$ and $\mathrm{H}-6^{\prime}$ ) can be seen. Cross-peak by three chemical bonds occurs less likely than by two chemical bonds in HMBC experiments. Therefore, we assigned the C-3' signal as having cross-peaks by one, and two chemical bonds, and the C-4' signal as having cross-peaks by one and two chemical bonds [44-46]. Chemical shifts of the other signals in the ${ }^{1} \mathrm{H}-\mathrm{NMR}$ and ${ }^{13} \mathrm{C}-\mathrm{NMR}$ spectra have only slightly changed. The signal from the three protons of the methyl group at C-6 remained at the same position as in the ${ }^{1} \mathrm{H}-\mathrm{NMR}$ spectrum of substrate 4 which indicates the presence of the methyl group in product $4 \mathbf{a}$. 
Table 3. ${ }^{1} \mathrm{H}-\mathrm{NMR}$ chemical shifts $\delta(\mathrm{ppm})$ and coupling constants $J(\mathrm{~Hz})$ of 6-methylflavanone (4) and products of its biotransformation 4a-4f in Acetone-d6, $600 \mathrm{MHz}$ (Supplementary Materials).

\begin{tabular}{|c|c|c|c|c|c|c|c|}
\hline \multirow{2}{*}{ Proton } & \multicolumn{7}{|c|}{ Compound } \\
\hline & 4 & $4 a$ & $4 \mathrm{~b}$ & $4 c$ & $4 d$ & $4 e$ & $4 f$ \\
\hline H-2 & $\begin{array}{c}5.59(\mathrm{dd}) \\
J_{2,3 a x}=13.0 \\
J_{2,3 e q}=2.8\end{array}$ & $\begin{array}{c}5.46(\mathrm{dd}) \\
J_{2,3 a x}=12.8 \\
J_{2,3 e q}=2.9\end{array}$ & $\begin{array}{c}5.52(\mathrm{dd}) \\
J_{2,3 a x}=13.0 \\
J_{2,3 e q}=2.8\end{array}$ & $\begin{array}{c}5.61(\mathrm{dd}) \\
J_{2,3 a x}=12.5 \\
J_{2,3 e q}=3.0\end{array}$ & $\begin{array}{c}5.48(\mathrm{dd}) \\
J_{2,3 a x}=12.8 \\
J_{2,3 e q}=2.9\end{array}$ & $\begin{array}{c}5.53(\mathrm{dd}) \\
J_{2,3 a x}=12.9 \\
J_{2,3 e q}=2.9\end{array}$ & $\begin{array}{c}5.36(\mathrm{dd}) \\
J=12.1 \\
J=1.9\end{array}$ \\
\hline $\mathrm{H}-3_{\mathrm{ax}}$ & $\begin{array}{c}3.11(\mathrm{dd}) \\
J_{3 a x, 2}=13.0 \\
J_{3 a x, 3 e q}=16.7\end{array}$ & $\begin{array}{c}3.11(\mathrm{dd}) \\
J_{3 a x, 2}=12.8 \\
J_{3 a x, 3 e q}=16.7\end{array}$ & $\begin{array}{c}3.16(\mathrm{dt}) \\
J=8.3 \\
J_{3 a x, 3 e q}=16.8\end{array}$ & $\begin{array}{c}3.13(\mathrm{dd}) \\
J_{3 a x, 2}=12.5 \\
J_{3 a x, 3 e q}=16.8\end{array}$ & $\begin{array}{c}3.15(\mathrm{dd}) \\
J_{3 a x, 2}=12.9 \\
J_{3 a x, 3 e q}=16.8\end{array}$ & $\begin{array}{c}3.12(\mathrm{dd}) \\
J_{3 a x, 2}=12.9 \\
J_{3 a x, 3 e q}=16.7\end{array}$ & $\begin{array}{c}2.43(\mathrm{dt}) \\
J=14.1 \\
J=2.2\end{array}$ \\
\hline $\mathrm{H}-3_{\mathrm{eq}}$ & $\begin{array}{c}2.85(\mathrm{~d}) \\
J_{3 \mathrm{eq}, 2}=2.9\end{array}$ & $\begin{array}{c}2.78(\mathrm{dd}) \\
J_{3 \mathrm{eq}, 2}=2.9 \\
J_{3 \mathrm{eq}, 3 \mathrm{ax}}=16.8\end{array}$ & $\begin{array}{c}2.79(\mathrm{dd}) \\
J_{3 \mathrm{eq}, 2}=2.9 \\
J_{3 \mathrm{eq}, 3 \mathrm{ax}}=16.8\end{array}$ & $\begin{array}{l}2.90(\mathrm{~d}) \\
J=3.2\end{array}$ & $\begin{array}{c}2.80(\mathrm{dd}) \\
J_{3 \mathrm{eq}, 2}=2.9 \\
J_{3 \mathrm{eq}, 3 \mathrm{ax}}=16.7\end{array}$ & $\begin{array}{c}2.79(\mathrm{dd}) \\
J_{3 \mathrm{eq}, 2}=2.9 \\
J_{3 \mathrm{eq}, 3 \mathrm{ax}}=16.8\end{array}$ & $\begin{array}{c}2.07 \text { (ddd) } \\
J=6.0, \\
J=3.6, \\
J=1.2\end{array}$ \\
\hline $\mathrm{H}-4$ & - & - & - & - & - & - & $\begin{array}{l}4.92(t) \\
J=2.8\end{array}$ \\
\hline H-5 & $7.63(\mathrm{~s})$ & $\begin{array}{c}7.61(\mathrm{~d}) \\
J_{5,7}=2.3\end{array}$ & $\begin{array}{c}7.83(\mathrm{~d}) \\
J_{5,7}=2.2\end{array}$ & $\begin{array}{c}7.82(\mathrm{~d}) \\
J_{5,7}=2.1\end{array}$ & $\begin{array}{c}7.82(\mathrm{~d}) \\
J_{5,7}=2.3\end{array}$ & $\begin{array}{c}7.62(\mathrm{~d}) \\
J_{5,7}=1.5\end{array}$ & $\begin{array}{c}7.22(\mathrm{~d}) \\
J_{5,7}=1.9\end{array}$ \\
\hline H-6 & - & - & - & - & - & - & - \\
\hline H-7 & $\begin{array}{c}7.40(\mathrm{dt}) \\
J=10.9 \\
J=4.7\end{array}$ & $7.39(\mathrm{~m})$ & $\begin{array}{l}7.61(\mathrm{dd}) \\
J_{7,8}=8.5 \\
J_{7,5}=2.2\end{array}$ & $\begin{array}{l}7.58(\mathrm{dd}) \\
J_{7,8}=8.5 \\
J_{7,5}=2.3\end{array}$ & $\begin{array}{l}7.56(\mathrm{dd}) \\
J_{7,8}=8.5 \\
J_{7,5}=2.1\end{array}$ & $7.39(\mathrm{~m})$ & $\begin{array}{l}7.08(\mathrm{dd}) \\
J_{7,8}=8.3 \\
J_{7,5}=1.9\end{array}$ \\
\hline H-8 & $\begin{array}{c}6.98(\mathrm{~d}) \\
J_{8,7}=8.4\end{array}$ & $\begin{array}{c}6.96(\mathrm{~d}) \\
J_{8,7}=8.4\end{array}$ & $\begin{array}{c}7.02(\mathrm{~d}) \\
J_{8,7}=8.6\end{array}$ & $\begin{array}{c}7.07(\mathrm{dd}) \\
J_{8,7}=8.3 \\
J=1.7\end{array}$ & $\begin{array}{c}7.02(\mathrm{~d}) \\
J_{8,7}=8.5\end{array}$ & $\begin{array}{c}6.95(\mathrm{~d}) \\
J_{8,7}=8.4\end{array}$ & $\begin{array}{c}6.80(\mathrm{~d}) \\
J_{8,7}=8.3\end{array}$ \\
\hline $\mathrm{H}-2^{\prime}$ & $\begin{array}{c}7.58(\mathrm{~d}) \\
J_{2^{\prime}, 3^{\prime}}=7.6\end{array}$ & $7.39(\mathrm{~m})$ & $7.41(\mathrm{~m})$ & $7.29(\mathrm{~m})$ & $\begin{array}{c}7.41(\mathrm{dd}) \\
J=4.5 \\
J=2.1\end{array}$ & $7.49(\mathrm{~m})$ & $\begin{array}{c}7.50(\mathrm{~d}) \\
J=7.2\end{array}$ \\
\hline $\mathrm{H}-3^{\prime}$ & $\begin{array}{l}7.45(\mathrm{t}) \\
J=7.5 \\
\end{array}$ & - & $6.90(\mathrm{~m})$ & - & - & $7.12(\mathrm{~m})$ & $\begin{array}{l}7.40(t) \\
J=7.6 \\
\end{array}$ \\
\hline $\mathrm{H}-4^{\prime}$ & $\begin{array}{c}7.40(\mathrm{dt}) \\
J=10.9 \\
J=4.7\end{array}$ & - & - & $\begin{array}{c}7.07(\mathrm{dd}) \\
J=8.3 \\
J=1.7\end{array}$ & - & - & $7.33(\mathrm{~m})$ \\
\hline $\mathrm{H}-5^{\prime}$ & $\begin{array}{l}7.45(\mathrm{t}) \\
J=7.5\end{array}$ & $\begin{array}{l}6.91(\mathrm{~d}) \\
J=8.2\end{array}$ & $6.90(\mathrm{~m})$ & $\begin{array}{l}7.35(\mathrm{t}) \\
J=8.0\end{array}$ & $\begin{array}{l}6.92(\mathrm{~d}) \\
J=8.2\end{array}$ & $7.12(\mathrm{~m})$ & $\begin{array}{l}7.40(t) \\
J=7.6\end{array}$ \\
\hline $\mathrm{H}-6^{\prime}$ & $\begin{array}{l}7.58(\mathrm{~d}) \\
J=7.6\end{array}$ & $\begin{array}{c}7.16(\mathrm{dt}) \\
J=2.0 \\
J=8.2\end{array}$ & $7.41(\mathrm{~m})$ & $\begin{array}{l}7.21(\mathrm{~d}) \\
J=7.7\end{array}$ & $\begin{array}{c}7.17(\mathrm{dd}) \\
J_{6^{\prime}, 5^{\prime}}=8.3 \\
J=1.9\end{array}$ & $7.49(\mathrm{~m})$ & $\begin{array}{l}7.50(\mathrm{~d}) \\
J=7.2\end{array}$ \\
\hline $\mathrm{H}-\mathrm{1}^{\prime \prime}$ & - & $\begin{array}{l}4.79(\mathrm{~d}) \\
J=7.9\end{array}$ & $\begin{array}{l}4.36(\mathrm{~d}) \\
J=7.8\end{array}$ & $\begin{array}{l}4.98(\mathrm{~d}) \\
J=7.8\end{array}$ & $\begin{array}{l}4.82(\mathrm{~d}) \\
J=7.9\end{array}$ & $\begin{array}{l}4.97(\mathrm{~d}) \\
J=7.8\end{array}$ & $\begin{array}{l}4.49(\mathrm{~d}) \\
J=7.8\end{array}$ \\
\hline $\mathrm{H}-2^{\prime \prime}$ & - & $\begin{array}{l}3.50(\mathrm{t}) \\
J=9.4\end{array}$ & $3.26(\mathrm{~m})$ & $3.48(\mathrm{~m})$ & $\begin{array}{l}3.50(\mathrm{t}) \\
J=8.2\end{array}$ & $\begin{array}{c}3.48 \text { (ddd) } \\
J=9.8 \\
J=5.0 \\
J=2.0\end{array}$ & $3.30(\mathrm{~m})$ \\
\hline $\mathrm{H}-3^{\prime \prime}$ & - & $3.63(\mathrm{~m})$ & $3.50(\mathrm{~m})$ & $\begin{array}{c}3.62(\mathrm{ddd}) \\
J=9.1 \\
J=7.6 \\
J=4.2\end{array}$ & $\begin{array}{l}3.63(\mathrm{~d}) \\
J=6.6\end{array}$ & $\begin{array}{l}3.63(\mathrm{t}) \\
J=9.0\end{array}$ & $3.52(\mathrm{~m})$ \\
\hline $\mathrm{H}-4^{\prime \prime}$ & - & $3.22(\mathrm{~m})$ & $3.10(\mathrm{~m})$ & $3.21(\mathrm{~m})$ & $3.21(\mathrm{~m})$ & $\begin{array}{c}3.21(\mathrm{dd}) \\
J=9.6 \\
J=9.1\end{array}$ & $\begin{array}{c}3.12(\mathrm{dd}) \\
J=9.6 \\
J=9.0\end{array}$ \\
\hline $\mathrm{H}-5^{\prime \prime}$ & - & $\begin{array}{c}3.45(\mathrm{ddd}) \\
J=9.8 \\
J=4.9 \\
J=1.9\end{array}$ & $3.26(\mathrm{~m})$ & $3.48(\mathrm{~m})$ & $3.46(\mathrm{~m})$ & $\begin{array}{c}3.48(\mathrm{ddd}) \\
J=9.8 \\
J=5.0 \\
J=2.0\end{array}$ & $3.30(\mathrm{~m})$ \\
\hline $\mathrm{H}-6^{\prime \prime}$ & - & $\begin{array}{c}3.85(\mathrm{dt}) \\
J=8.5 \\
J=4.4 \\
3.69(\mathrm{~m})\end{array}$ & $\begin{array}{l}3.82(\mathrm{~d}) \\
J=10.0 \\
3.66(\mathrm{~m})\end{array}$ & $\begin{array}{c}3.84(\mathrm{dd}) \\
J=9.3 \\
J=5.2 \\
3.68(\mathrm{~m})\end{array}$ & $\begin{array}{l}3.85(\mathrm{~d}) \\
J=10.6 \\
3.68(\mathrm{~m})\end{array}$ & $\begin{array}{l}3.83(\mathrm{~d}) \\
J=12.2 \\
3.69(\mathrm{~m})\end{array}$ & $\begin{array}{c}3.89(\mathrm{~m}) \\
3.71(\mathrm{dt}) \\
J=11.4 \\
J=5.8\end{array}$ \\
\hline$-\mathrm{CH}_{2}^{-}$ & - & - & $\begin{array}{c}4.86(\mathrm{dd}) \\
J=11.8 \\
J=2.6 \\
4.61(\mathrm{dt}) \\
J=11.7 \\
J=2.7\end{array}$ & $\begin{array}{l}4.61(\mathrm{~d}) \\
J=5.2\end{array}$ & $4.61(\mathrm{~m})$ & - & - \\
\hline C6- $\mathrm{CH}_{3}$ & $2.32(\mathrm{~s})$ & $2.31(\mathrm{~s})$ & - & - & - & $2,31(\mathrm{~s})$ & $2.27(\mathrm{~s})$ \\
\hline $\mathrm{C}^{\prime \prime}-\mathrm{OCH}_{3}$ & - & $3.55(\mathrm{~s})$ & $3.53(\mathrm{~s})$ & $3.56(\mathrm{~s})$ & $3.55(\mathrm{~s})$ & $3.56(\mathrm{~s})$ & $3.54(\mathrm{~s})$ \\
\hline
\end{tabular}


Table 4. ${ }^{13} \mathrm{C}-\mathrm{NMR}$ chemical shifts $\delta$ (ppm) of 6-methylflavanone (4) and products of its biotransformation 4a-4f in Acetone-d6, $151 \mathrm{MHz}$ (Supplementary Materials).

\begin{tabular}{|c|c|c|c|c|c|c|c|}
\hline \multirow{2}{*}{ Carbon } & \multicolumn{7}{|c|}{ Compound } \\
\hline & 4 & $4 a$ & $4 b$ & $4 c$ & $4 d$ & $4 e$ & $4 f$ \\
\hline$C-2$ & 80.3 & 80.0 & 80.4 & 80.0 & 80.1 & 80.0 & 73.8 \\
\hline$C-3$ & 45.1 & 44.9 & 44.8 & 44.9 & 44.7 & 44.9 & 37.5 \\
\hline$C-4$ & 191.9 & 192.3 & 192.3 & 191.9 & 192.3 & 192.2 & 70.2 \\
\hline$C-4 a$ & 121.6 & 121.6 & 121.5 & 121.5 & 121.5 & 121.5 & 120.5 \\
\hline$C-5$ & 127.0 & 126.9 & 126.7 & 125.2 & 125.2 & 126.9 & 132.7 \\
\hline C-6 & 131.6 & 131.5 & 132.3 & 136.7 & 136.5 & 131.5 & 129.6 \\
\hline C-7 & 137.7 & 137.7 & 136.7 & 135.6 & 135.5 & 137.8 & 131.5 \\
\hline C-8 & 118.8 & 118.8 & 118.8 & 117.1 & 118.8 & 118.7 & 117.5 \\
\hline C-8a & 160.5 & 160.6 & 162.0 & 161.4 & 161.5 & 160.5 & 154.1 \\
\hline$C-1^{\prime}$ & 140.5 & 131.8 & 131.0 & 141.9 & 131.6 & 133.9 & 142.7 \\
\hline $\mathrm{C}-2^{\prime}$ & 127.3 & 117.9 & 129.0 & 115.4 & 117.7 & 128.7 & 127.1 \\
\hline$C-3^{\prime}$ & 129.5 & 146.1 & 116,2 & 158.9 & 146.1 & 117.3 & 129.2 \\
\hline $\mathrm{C}-4^{\prime}$ & 129.3 & 149.0 & 158.7 & 118.8 & 149.0 & 158.8 & 128.6 \\
\hline$C-5^{\prime}$ & 129.5 & 116.8 & 116.2 & 130.5 & 116.8 & 117.3 & 129.2 \\
\hline$C-6^{\prime}$ & 127.3 & 123.3 & 129.0 & 120.8 & 123.3 & 128.7 & 127.1 \\
\hline$C-1^{\prime \prime}$ & - & 104.2 & 103.0 & 101.5 & 104.0 & 101.6 & 101.4 \\
\hline$C-2^{\prime \prime}$ & - & 75.0 & 75.2 & 75.0 & 74.9 & 74.9 & 75.3 \\
\hline$C-3^{\prime \prime}$ & - & 77.5 & 78.1 & 78.1 & 77.5 & 77.9 & 78.2 \\
\hline$C-4^{\prime \prime}$ & - & 80.1 & 80,5 & 80.1 & 80.2 & 80.1 & 80.6 \\
\hline$C-5^{\prime \prime}$ & - & 77.3 & 76.9 & 77.0 & 77.2 & 77.0 & 76.9 \\
\hline$C-6^{\prime \prime}$ & - & 62.0 & 62.4 & 62.1 & 62.0 & 62.0 & 62.6 \\
\hline $\mathrm{C} 6-\mathrm{CH}_{2}-\mathrm{OH}$ & - & - & 70.8 & 63.9 & 63.9 & - & - \\
\hline $\mathrm{C}-4^{\prime \prime}-\mathrm{OC} \mathrm{H}_{3}$ & - & 60.6 & 60.5 & 60.5 & 60.6 & 60.5 & 60.5 \\
\hline $\mathrm{C} 6-\mathrm{CH}_{3}$ & 20.4 & 20.4 & - & - & - & 20.4 & 20.5 \\
\hline
\end{tabular}

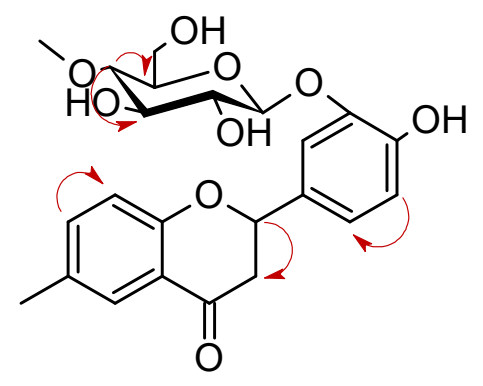

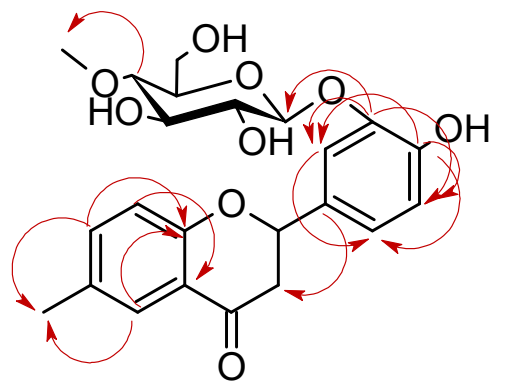

Scheme 5. Key COSY (on the left) and HMBC (on the right) correlations for the structure elucidation of product 4 a.

In the case of compound $\mathbf{4 b}$, the sugar moiety was attached to the hydroxyl group-previously formed by microbial oxidation of the methyl group-because in the HMBC spectrum the proton at the anomeric carbon atom $(\delta=4.78 \mathrm{ppm})$ was coupled with the $\mathrm{C}-6-\mathrm{CH}_{2}$ - signal $(\delta=70.3 \mathrm{ppm})$. Moreover, the signal from the three protons of the methyl group at C- 6 present in the ${ }^{1} \mathrm{H}-\mathrm{NMR}$ spectrum $(\delta=2.32 \mathrm{ppm})$ of substrate 4 disappeared and two signals appeared from protons at $4.86 \mathrm{ppm}$ and 
$4.61 \mathrm{ppm}$ (unequal protons from methylene group), which confirms attachment of the glucose unit to the methylene bridge at C-6. In the ${ }^{1} \mathrm{H}-\mathrm{NMR}$ spectrum, proton signals of the flavanone ring $\mathrm{A}$ became only slightly shifted because of it. Moreover, signals from protons of the ring B became shifted, indicating another substitution in ring B. Two multiplets from the protons at C-2' and C- $6^{\prime}$ $(\delta=7.41 \mathrm{ppm})$ and at $C-3^{\prime}$ and $C-5^{\prime}(\delta=6.90 \mathrm{ppm})$ were observed and the signal from proton at $C-4^{\prime}$ was missing which indicates a substitution at $C-4^{\prime}$. In the ${ }^{13} C-N M R$ spectrum $C-4^{\prime}$ signal $(\delta=158.7 \mathrm{ppm})$, which was shifted from $\delta=129.3 \mathrm{ppm}$, indicates the attachment of a hydroxyl group. Chemical shifts of the other signals in the ${ }^{1} \mathrm{H}-\mathrm{NMR}$ and ${ }^{13} \mathrm{C}-\mathrm{NMR}$ spectra have only slightly changed that signalize that the flavanone skeleton remained intact.
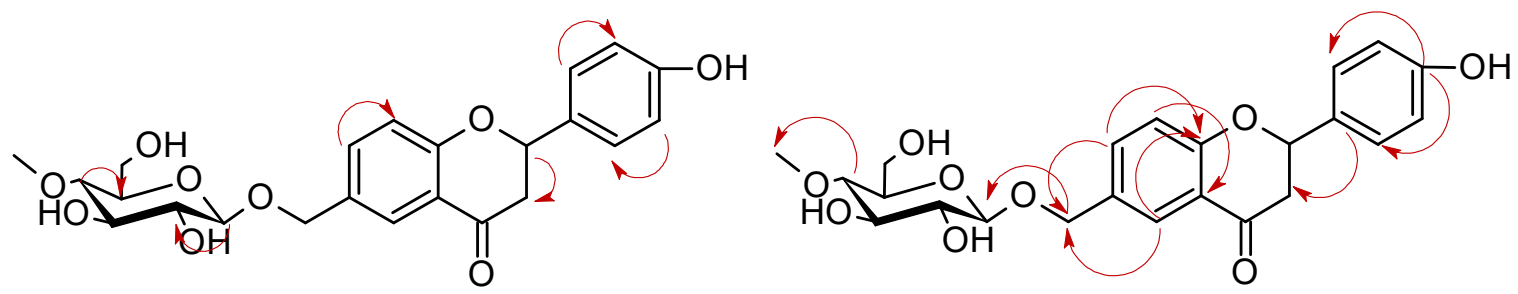

Scheme 6. Key COSY (on the left) and HMBC (on the right) correlations for the structure elucidation of product $4 \mathrm{~b}$.

Based on the HMBC spectrum, in compound 4c, a sugar moiety was attached at C- $3^{\prime}$, due to the proton at the anomeric carbon atom $(\delta=4.98 \mathrm{ppm})$ being coupled with the $C-3^{\prime}$ signal $(\delta=158.9 \mathrm{ppm})$, which was shifted from $\delta=129.5 \mathrm{ppm}$, and points out the attachment of an electronegative atom. Moreover, protons in the ${ }^{1} \mathrm{H}-\mathrm{NMR}$ spectrum at $\mathrm{C}-2^{\prime}$ and $\mathrm{C}-6^{\prime}$ became non-equivalent. In the ${ }^{1} \mathrm{H}-\mathrm{NMR}$ spectrum shifted proton signals of ring $B$ can be observed: multiplet from proton at $C-2^{\prime}(\delta=7.29 \mathrm{ppm})$, triplet from proton at $C-5^{\prime}(\delta=7.35 \mathrm{ppm})$ and doublet from proton at $C-6^{\prime}(\delta=7.21 \mathrm{ppm})$, and signal from proton at $C-4^{\prime}$ that overlapped with the signal from proton at C-8 $(\delta=7.07 \mathrm{ppm})$. In the COSY spectrum proton at $\mathrm{C}-2^{\prime}$ became isolated, confirming substitution at $\mathrm{C}-3^{\prime}$. Moreover, the signal from the three protons of the methyl group at C-6 present in the ${ }^{1} \mathrm{H}-\mathrm{NMR}$ spectrum $(\delta=2.32 \mathrm{ppm})$ of substrate 4 disappeared. The presence of another moiety-a hydroxymethyl group at C-6 can be noticed in the ${ }^{13} \mathrm{C}-\mathrm{NMR}$ spectrum, because the signal from C-6 was shifted from $\delta=131.6 \mathrm{ppm}$ to $\delta=136.7 \mathrm{ppm}$. It was also confirmed by the appearance of a signal from two protons at $4.61 \mathrm{ppm} \mathrm{[47]}$ and slightly shifted signals from protons of ring A: doublet from the proton at $C-5(\delta=7.82 \mathrm{ppm})$, doublet of doublets from the proton at C-7 $(\delta=7.58 \mathrm{ppm})$ and doublet of doublets from the proton at $\mathrm{C}-8(\delta=7.07 \mathrm{ppm})$. Chemical shifts of the other signals in the ${ }^{1} \mathrm{H}-\mathrm{NMR}$ and ${ }^{13} \mathrm{C}-\mathrm{NMR}$ spectra have only slightly changed which indicates that the flavanone skeleton remained unaffected.

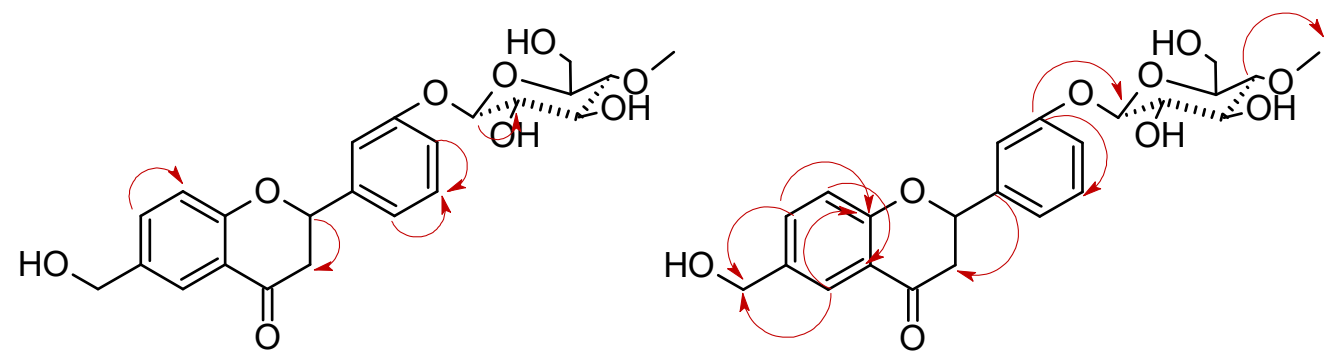

Scheme 7. Key COSY (on the left) and HMBC (on the right) correlations for the structure elucidation of product $4 c$.

Based on the HMBC spectrum, a sugar moiety was attached to $C-3^{\prime}$ in the case of compound $4 \mathrm{~d}$, due to the proton at the anomeric carbon atom $(\delta=4.81 \mathrm{ppm})$ being coupled with the $C-3^{\prime}$ signal $(\delta=146.1 \mathrm{ppm})$, which was shifted from $\delta=129.5 \mathrm{ppm}$. Additionally, protons in the ${ }^{1} \mathrm{H}-\mathrm{NMR}$ spectrum at C-2' and C-6' became non-equivalent. Shifted signals can be observed: one doublet of doublets 
from the proton at $C-2^{\prime}(\delta=7.41 \mathrm{ppm})$, one doublet of triplets at $C-6^{\prime}(\delta=7.17 \mathrm{ppm})$, and one doublet from the proton at $C-5^{\prime}(\delta=6.92 \mathrm{ppm})$. In the ${ }^{13} \mathrm{C}-\mathrm{NMR}$ spectrum signal from $C-4^{\prime}(\delta=149.0 \mathrm{ppm})$ and signal from C-6 $(\delta=136.5 \mathrm{ppm})$ was also shifted compared with the signals from substrate 4 $\delta=129.3 \mathrm{ppm}$ and $\delta=131.6 \mathrm{ppm}$, respectively. These changes indicate the introduction of a hydroxyl group at C- $4^{\prime}$ and hydroxymethyl group at C-6. Methylglucosyl moiety was attached to C- $3^{\prime}$ and hydroxyl moiety to $C-4^{\prime}$ same as in product $4 \mathbf{b}$, which was confirmed by cross-peaks in the HMBC spectrum [44-46]. Signals from the protons of ring A were only slightly changed, but exchange of a methyl group on the hydroxymethyl group at C- 6 was confirmed by the disappearance of the signal from the three protons of the methyl moiety that was present in the ${ }^{1} \mathrm{H}-\mathrm{NMR}$ spectrum $(\delta=2.32 \mathrm{ppm})$ of substrate 4 and the appearance of a signal from two protons at $4.61 \mathrm{ppm}$ [47].
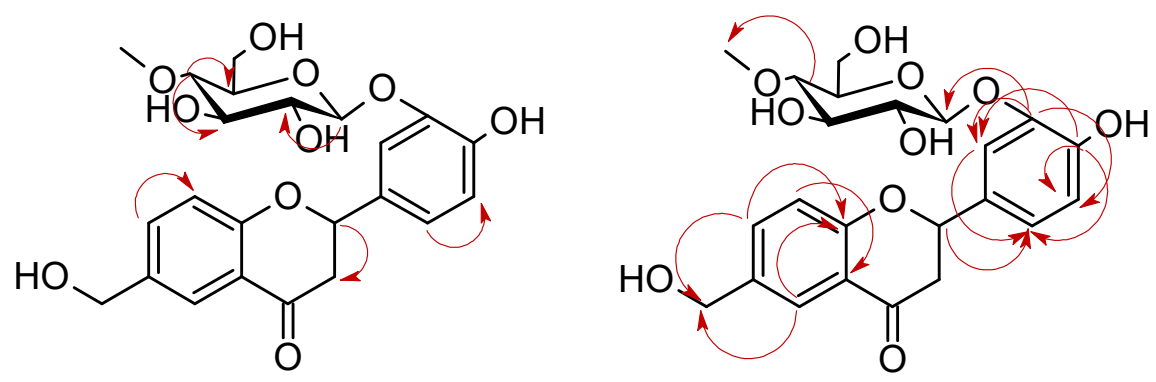

Scheme 8. Key COSY (on the left) and HMBC (on the right) correlations for the structure elucidation of product $4 \mathbf{d}$.

Glycosylations of flavanones performed by B. bassiana strains have already been described in the scientific literature. Isoxanthohumol and 8-prenylnaringenin were transformed by B. bassiana AM278 into their 7-O- $\beta$-D-( $4^{\prime \prime}-O$-methyl)-glucosides [48]. Other flavanones, like pinocembrin, naringenin, eriodicytol and hesperetin were glycosylated and $4^{\prime \prime}-O$-methyl-glycosylated at C-7 in the cultures of B. bassiana AM278. Moreover, hesperetin biotransfromation resulted in additional products glycosylated and 4"-O-methyl-glycosylated at C-3' [49]. The strain B. bassiana $\mathrm{KCH}$ J1.5 used in the currently presented studies showed a different regioselectivity of glycosylation. Interestingly $B$. bassiana $\mathrm{KCH} \mathrm{J1.5} \mathrm{was} \mathrm{also} \mathrm{able} \mathrm{to} \mathrm{hydroxylate} \mathrm{6-methyl} \mathrm{moiety} \mathrm{in} \mathrm{products} \mathbf{4 b} \mathbf{b} \mathbf{4 d}$. Presence of the four biotransformation products with different moieties attached indicates the involvement of a few enzymes in the transformation of 6-methylflavanone (4) in the culture of B. bassiana $\mathrm{KCH} \mathrm{J1.5.} \mathrm{In} \mathrm{the} \mathrm{case} \mathrm{of}$ product $4 \mathbf{b}$ ( $4^{\prime}$-hydroxyflavanone 6-methylene-O- $\beta$-D-( $4^{\prime \prime}-O$-methyl)-glucopyranoside) hydroxylation took place at $\mathrm{C}-4^{\prime}$ and $\mathrm{C}-6-\mathrm{CH}_{3}$, followed by attachment of the glucose unit to hydroxylmethyl group $\left(-\mathrm{CH}_{2}-\mathrm{OH}\right)$ at $\mathrm{C}-6$. The presumable course of microbial transformation of 6-methylflavanones is shown in the Scheme 9.<smiles>Cc1ccc2c(c1)C(=O)CC(c1ccccc1)O2</smiles>

Scheme 9. The probable course of transformation of 6-methylflavanones.

\subsection{Biotransformations of 6-methylflavanone (4) in the culture of I. fumosorosea KCH J2}

6-Methylflavanone (4) was also utilized in a 10-day biotransformation in the culture of I. fumosorosea $\mathrm{KCH} \mathrm{J2}$ and gave two biotransformation products: 6-methylflavanone $4^{\prime}-O-\beta$-D-(4"-O-methyl)-glucopyranoside (4e) with $22.1 \%$ yield and 2-phenyl-6-methylchromane 4 -O- $\beta$-D-(4"'-O-methyl)-glucopyranoside (4f) with $23.3 \%$ yield (Scheme 10$)$. 


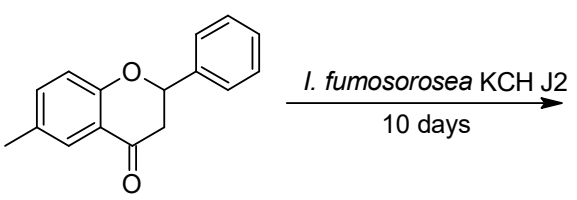

4<smiles>Cc1ccc2c(c1)C(=O)CC(c1ccc(OC(O)C(O)OC(O)C(O)O)cc1)O2</smiles>

$4 \mathrm{e}$

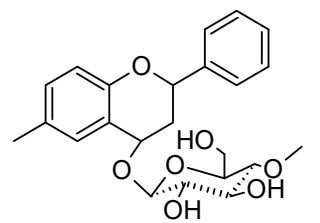

$4 f$

Scheme 10. Microbial transformation of 6-methylflavanone (4) in I. fumosorosea KCH J2 culture.

The products $4 \mathbf{e}$ and $\mathbf{4 f}$ were analyzed by ${ }^{1} \mathrm{H}-\mathrm{NMR}$ and ${ }^{13} \mathrm{C}-\mathrm{NMR}$ spectroscopy which allowed for the establishment of their chemical structures (Tables 3 and 4, Schemes 11 and 12).

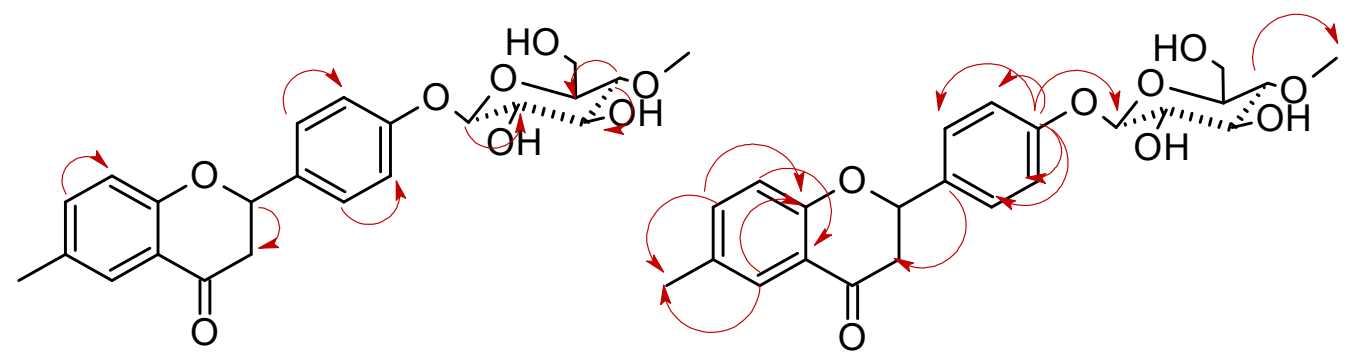

Scheme 11. Key COSY (on the left) and HMBC (on the right) correlations for the structure elucidation of product $4 \mathbf{e}$.

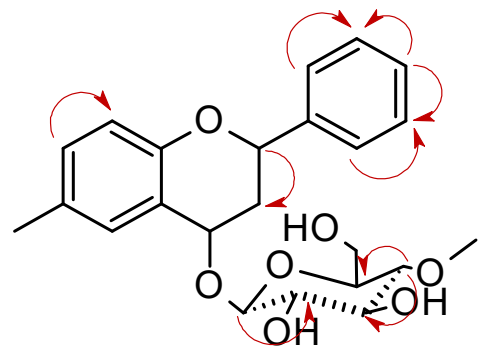

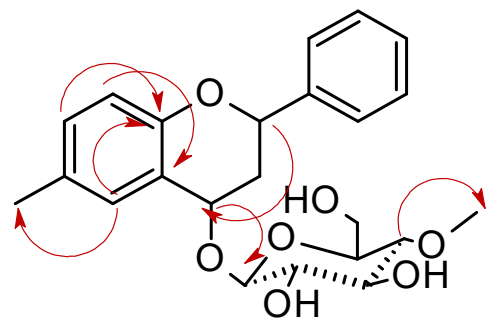

Scheme 12. Key COSY (on the left) and HMBC (on the right) correlations for the structure elucidation of product $4 \mathbf{f}$.

The presence of a glucose unit in compounds $4 \mathbf{e}$ and $\mathbf{4 f}$ was confirmed by five characteristic carbon signals observed in the region from about $\delta=80.0 \mathrm{ppm}$, to about $\delta=62.0 \mathrm{ppm}$, in the ${ }^{13} \mathrm{C}-\mathrm{NMR}$ spectra, as well as proton signals of $\delta \mathrm{H}$ ranging from about $\delta=3.9 \mathrm{ppm}$, to $\delta=3.1 \mathrm{ppm}$ in the ${ }^{1} \mathrm{H}-\mathrm{NMR}$ spectra. Additionally, the attachment of a sugar unit to substrate 4 was confirmed by a one-proton doublet at the anomeric carbon atom at $\delta=4.49 \mathrm{ppm}$ in the ${ }^{1} \mathrm{H}-\mathrm{NMR}$ spectrum of $4 \mathrm{e}, \delta=4.97 \mathrm{ppm}$ in the ${ }^{1} \mathrm{H}$-NMR spectrum of $4 \mathbf{f}$. The $\beta$-configuration of the glucose unit was proved for $4 \mathbf{e}$ and $4 \mathbf{f}$ by the coupling constant $(J=7.8 \mathrm{~Hz})$ for the anomeric proton. A three-proton singlet at about $\delta=3.6 \mathrm{ppm}$ in the ${ }^{1} \mathrm{H}-\mathrm{NMR}$ spectra and the corresponding signal at $\delta=60.5 \mathrm{ppm}$ in the ${ }^{13} \mathrm{C}-\mathrm{NMR}$ spectra of $4 \mathrm{e}$ and $\mathbf{4 f}$ evidences that one of the hydroxyl groups of sugar unit has been methylated. $O$-methylation occurred at the C-4" hydroxyl group of the glucose unit. It was detected in the HMBC spectrum, where the proton signal due to $-\mathrm{OCH}_{3}$ was correlated with the signal of $C-4^{\prime \prime}$ (about $\delta=80 \mathrm{ppm}$ ) in the glucose unit. 
Based on the HMBC spectrum, a sugar moiety was attached to C- $4^{\prime}$ in the case of compound $4 \mathrm{e}$, due to the proton at the anomeric carbon atom $(\delta=4.78 \mathrm{ppm})$ being coupled with the C $-4^{\prime}$ signal $(\delta=158.8 \mathrm{ppm})$, which was shifted from $\delta=129.3 \mathrm{ppm}$. In the ${ }^{1} \mathrm{H}-\mathrm{NMR}$ spectrum, multiplets from protons at $C-2^{\prime}$ and $C-6^{\prime}(\delta=7.49 \mathrm{ppm})$ and from protons at $C-3^{\prime}$ and $C-5^{\prime}(\delta=7.12 \mathrm{ppm})$ can be observed, which is characteristic of an $\mathrm{AA}^{\prime} \mathrm{BB}^{\prime}$ coupling system, signalizing the presence of flavanone ring B substitution at C- $4^{\prime}$. Chemical shifts of the other signals in the ${ }^{1} \mathrm{H}-\mathrm{NMR}$ and ${ }^{13} \mathrm{C}-\mathrm{NMR}$ spectra have only slightly changed, which indicates that the flavanone skeleton remained intact. The signal from the three protons of the methyl group at C-6 remained at the same position as in the ${ }^{1} \mathrm{H}-\mathrm{NMR}$ spectrum of substrate 4 , which means that the methyl group in product $4 \mathbf{e}$ was present.

Based on the HMBC spectrum, in the case of product $4 \mathbf{f}$, glycosylation occurred at C-4, due to the proton at the anomeric carbon atom $(\delta=4.49 \mathrm{ppm})$ being coupled with the $C-4$ signal $(\delta=70.2 \mathrm{ppm})$, which was shifted from $\delta=191.9 \mathrm{ppm}$, indicating reduction of the carbonyl group at $C-4$. Furthermore, in the ${ }^{1} \mathrm{H}-\mathrm{NMR}$ spectrum, a triplet at $\delta=4.92 \mathrm{ppm}$ appeared from one-proton at $\mathrm{C}-4$. Moreover, only slightly shifted signals from all ten protons from substrate 4 were visible, confirming the inability of another position of substitution. A doublet of doublets at $\delta=5.36 \mathrm{ppm}$ from one proton at C-2 became shifted from $\delta=5.59 \mathrm{ppm}$, the same as the signals from the pseudo-axial and pseudo-equatorial protons at C-3, respectively $(\delta=2.43$ ppm shifted from $\delta=3.11 \mathrm{ppm}$ and $\delta=2.07 \mathrm{ppm}$ shifted from $\delta=2.85 \mathrm{ppm}$ ). In the COSY spectrum there was a correlation between proton $3_{\mathrm{ax}}$ and $3_{\mathrm{eq}}$ with a new signal from the proton at C-4. In the HMBC spectrum correlations between the proton at C-5 and the carbon at C-4, and between the pseudo-axial proton at $\mathrm{C}-3$ and the carbon at $\mathrm{C}-4$, and between the proton at $\mathrm{C}-\mathrm{1}^{\prime \prime}$ and the carbon at C-4 were also present, which confirms that reduction and glycosylation occurred at $\mathrm{C}-4$. The signal from the three protons of the methyl group at C-6 remained at the same position as in the ${ }^{1} \mathrm{H}-\mathrm{NMR}$ spectrum of substrate 4 which indicates the presence of the methyl group in product $4 \mathrm{f}$.

The first product of the biotransformations presented above-6-methylflavanone $4^{\prime}-O-\beta$-D-(4' ${ }^{\prime \prime}-O$-methyl)-glucopyranoside $(4 \mathbf{e})$-is analogous to the 6-methoxyflavanone $4^{\prime}-O-\beta-\mathrm{D}-\left(4^{\prime \prime}-O-m e t h y l\right)$-glucopyranoside that was obtained in the microbial transformations of 6-methoxyflavanone by the same strain, I. fumosorosea $\mathrm{KCH}$ J2 [15]. Glycosylation at C-4' also occurred in the biotransformation of naringenin in the culture of I. fumosorosea ACCC 37814, performed by Dou et al. [16]. More unusual, is the second biotransformation product-2-phenyl-6-methylchromane 4-O- $\beta$-D-(4"-O-methyl)-glucopyranoside (4f). We assume that attachment of the glycosyl moiety at C-4 was preceded by the carbonyl group reduction, which was previously observed as a result of 2'-methoxyflavanone and 3'-methoxyflavanone biotransformations [15]. However, subsequent glycosylation at the same position has never been observed before. In each biotransformation product a methyl moiety at C-6 was retained, indicating that I. fumosorosea $\mathrm{KCH} \mathrm{J2}$ was not able to remove this moiety, unlike B. bassiana $\mathrm{KCH} \mathrm{J} 1.5$.

\section{Materials and Methods}

\subsection{Substrates}

The substrates for biotransformations were obtained by two-step synthesis (Scheme 1). The first step was Claisen-Schmidt condensation between $2^{\prime}$-hydroxy-5'-methylacetophenone (1) and benzaldehyde (2) (purchased from Sigma-Aldrich (St. Louis, MO, USA)) dissolved in methanol, under alkaline conditions at high temperature, according to the method described previously [50-53]. 2'-Hydroxy-5'-methylchalcone (3) was obtained with a 50.1\% yield and was used as the biotransformation substrate, and also as substrate in the second step of the synthesis. 6-Methylflavanone (4) was obtained by cyclization of $2^{\prime}$-hydroxy-5'-methylchalcone (3) in the presence of sodium acetate $[54,55]$ with $62.3 \%$ yield.

The physical data, including the retention time $\mathrm{t}_{\mathrm{R}}(\mathrm{min})$, the optical rotation $[\alpha]_{D}^{20}$, and concentration c (M), as well as NMR spectral data of the resulting compounds 3 and 4 are presented below, and in Tables 1-4, and in the Supplementary Materials. 
3.1.1. 2'-Hydroxy-5'-methylchalcone (3)

$$
\mathrm{C}_{16} \mathrm{H}_{14} \mathrm{O}_{2}, \mathrm{M}_{\mathrm{W}}=238.28[\mathrm{M}+\mathrm{H}]^{+} 239.1054 ;{ }^{1} \mathrm{H}-\mathrm{NMR} \text {, see Table } 1,{ }^{13} \mathrm{C}-\mathrm{NMR} \text {, see Table } 2 .
$$

3.1.2. 6-Methylflavanone (4)

$\mathrm{C}_{16} \mathrm{H}_{14} \mathrm{O}_{2}, \mathrm{M}_{\mathrm{w}}=238.28,[\mathrm{M}+\mathrm{H}]^{+} 239.1086 ;[\alpha]_{D}^{20}=0(\mathrm{c}=0.65$, acetone $) ;{ }^{1} \mathrm{H}-\mathrm{NMR}$, see Table 3, ${ }^{13} \mathrm{C}-\mathrm{NMR}$, see Table 4.

\subsection{Microorganisms}

The studies were carried out using two strains of entomopathogenic filamentous fungi I. fumosorosea $\mathrm{KCH} \mathrm{J2}$ and B. bassiana KCH J1.5, that were collected from the Department of Chemistry of Wrocław University of Environmental and Life Sciences, Poland. The description of material collection, propagation of structures of the fungi, and genetic identification have already been described in our previous papers [12,37]. The microorganisms were maintained on potato slants at $4^{\circ} \mathrm{C}$ and subcultured before use in the experiments.

\subsection{Analysis}

The course of the biotransformation was assessed by chromatographic methods (TLC, HPLC). TLC analysis was carried out using TLC Silica gel 60/Kieselguhr F254 (0.2 mm thick) plates (Merck, Darmstadt, Germany). The developing system was a mixture of chloroform and methanol (9:1 v/v). The products were observed (without additional visualization) under the ultraviolet lamp at the two wavelengths $254 \mathrm{~nm}$ and $365 \mathrm{~nm}$.

HPLC analyses were performed on a Dionex Ultimate 3000 instrument (Thermo Fisher Scientfic, Waltham, MA, USA) with a diode array detector using an analytical octadecyl silica (ODS) 2 column $(4.6 \times 250 \mathrm{~mm}$, Waters, Milford, MA, USA $)$ and pre-column. The gradient program was as follows: initial conditions $-32.5 \% \mathrm{~B}$ in $\mathrm{A}, 4 \mathrm{~min}-40 \% \mathrm{~B}$ in $\mathrm{A}, 8 \mathrm{~min}-40 \% \mathrm{~B}$ in $\mathrm{A}, 10 \mathrm{~min}-45 \% \mathrm{~B}$ in $\mathrm{A}$, $15 \mathrm{~min}-95 \% \mathrm{~B}$ in A, $18 \mathrm{~min}-95 \% \mathrm{~B}$ in A, $19 \mathrm{~min}-32.5 \% \mathrm{~B}$ in A, $23 \mathrm{~min}-32.5 \% \mathrm{~B}$ in A. The flow rate was $1 \mathrm{~mL} / \mathrm{min}$, the injection volume was $5 \mu \mathrm{L}$, and detection wavelength $280 \mathrm{~nm}$.

Separation of the products obtained by the scale-up biotransformation was attained using 500 and $1000 \mu \mathrm{m}$ preparative TLC silica gel plates (Analtech, Gehrden, Germany). After elution of the compounds from the adsorbent on TLC plates with chloroform and methanol $(9: 1 v / v)$ as eluents, compounds were extracted from the selected gel fractions using $20 \mathrm{~mL}$ ethyl acetate 3 times. The extracts from a single fraction were combined and ethyl acetate was evaporated under reduced pressure.

NMR analyses $\left({ }^{1} \mathrm{H}-\mathrm{NMR},{ }^{13} \mathrm{C}-\mathrm{NMR}, \mathrm{COSY}\right.$, Heteronuclear Multiple Quantum Correlation (HSQC), HMBC) were performed using a DRX Avance ${ }^{\mathrm{TM}} 600 \mathrm{MHz}$ NMR spectrometer (Bruker, Billerica, MA, USA). The prepared samples were dissolved in deuterated acetone, except 3 dissolved in deuterated chloroform.

Optical rotation was measured using digital polarimeter P-2000-Na (ABL \& E-JASCO, Kraków, Poland).

Molecular formulas of products were confirmed by UPLC-qTOF-MS/MS analysis. Identification of compounds was performed as described previously, with slight modifications [56], on the Acquity ultra-performance liquid chromatography (UPLC) system, coupled with a quadrupole-time of flight (q-TOF) MS instrument (UPLC/Synapt q-TOF MS, Waters Corp., Milford, MA, USA), with an electrospray ionization (ESI) source. The separation was achieved on the Cadenza CD-C18 UP (75 $\mathrm{mm} \times 2.0 \mathrm{~mm}$ i.d., $3 \mu \mathrm{m}$ ) column (Imtakt, Kyoto, Japan). The mobile phase was a mixture of $0.1 \%$ aqueous formic acid $v / v(\mathrm{~A})$ and acetonitrile (B). The gradient program was as follows: initial conditions $-1 \% \mathrm{~B}$ in A, $12 \mathrm{~min}-25 \% \mathrm{~B}$ in A, $19 \mathrm{~min}-100 \% \mathrm{~B}, 20 \mathrm{~min}-1 \% \mathrm{~B}$ in A. The flow rate was $0.45 \mathrm{~mL} / \mathrm{min}$, and the injection volume was $5 \mu \mathrm{L}$. The column was operated at $30^{\circ} \mathrm{C}$. The major operating parameters for the q-TOF MS were set as follows: capillary voltage $2.0 \mathrm{kV}$, cone voltage $40 \mathrm{~V}$, cone gas flow of $11 \mathrm{~L} / \mathrm{h}$, collision energy $28-30 \mathrm{eV}$, source temperature $100{ }^{\circ} \mathrm{C}$, desolvation temperature 
$250{ }^{\circ} \mathrm{C}$, collision gas, argon; desolvation gas (nitrogen) flow rate, $600 \mathrm{~L} / \mathrm{h}$; data acquisition range, m/z 100-2000 Da; ionization mode, negative and positive. The data were collected with Mass-Lynx V 4.1 software. The runs were monitored at a wavelength of $254 \mathrm{~nm}$.

\subsection{Screening Procedure}

Experiments were carried out using Sabouraud medium $(10 \mathrm{~g}$ aminobac, $30 \mathrm{~g}$ glucose, $1 \mathrm{~L}$ distilled water). The microorganism was transferred to a $300 \mathrm{~mL}$ Erlenmeyer flask with $100 \mathrm{~mL}$ medium. Pre-incubation was carried out on a rotary shaker $(140 \mathrm{rpm})$ at $25^{\circ} \mathrm{C}$ for $72 \mathrm{~h}$. The screening was also performed in $300 \mathrm{~mL}$ Erlenmeyer flasks with $100 \mathrm{~mL}$ of Sabouraud liquid medium. The pre-grown culture $(0.5 \mathrm{~mL})$ was transferred to an Erlenmeyer flask, and after $72 \mathrm{~h}$ incubation, $10 \mathrm{mg}$ of substrate 3 or 4, dissolved in $0.5 \mathrm{~mL}$ of dimethyl sulfoxide, was added. The molar concentrations of substrates 3 and 4 were $0.42 \mathrm{mM}$. The biotransformation was run under the same conditions as pre-incubation. After 3, 6 and 9 days of substrate incubation samples were collected and extracted once with $30 \mathrm{~mL}$ of ethyl acetate. The extracts were dried with anhydrous magnesium sulfate for $5 \mathrm{~min}$, concentrated in vacuo and analyzed by TLC and HPLC methods. Stability of the substrate was evaluated under identical conditions, without using a biocatalyst. Control cultivation with no substrate has also been performed.

\subsection{The Semi-Preparative Biotransformations}

The semi-preparative biotransformations were performed in $2 \mathrm{~L}$ flasks with $500 \mathrm{~mL}$ of the Sabouraud medium ( $10 \mathrm{~g}$ aminobac, $30 \mathrm{~g}$ glucose, $1 \mathrm{~L}$ distilled water) each. The pre-incubation culture $(1 \mathrm{~mL})$ was transferred to the flask and incubated for $72 \mathrm{~h}$ same as during the screening procedure. Afterwards, $50 \mathrm{mg}$ of substrate 3 or 4 , dissolved in $2.5 \mathrm{~mL}$ of dimethyl sulfoxide, was added and the cultures were shaken on a rotary shaker for 10 days. The molar concentrations of substrates 3 and 4 were $0.42 \mathrm{~mm}$. After the confirmation of complete substrate conversion (or lack of further substrate conversion) metabolites were extracted 2 times using each time $300 \mathrm{~mL}$ of ethyl acetate. The combined extracts were dried with anhydrous magnesium sulfate for $5 \mathrm{~min}$ and then concentrated using a rotary evaporator. Biotransformation products were separated using preparative TLC plates and analyzed by NMR and UPLC-qTOF-MS/MS.

The physical data, including the retention time $t_{R}(\min )$, the optical rotation $[\alpha]_{D}^{20}$, and concentration c (M), as well as NMR spectral data of the resulting compounds $\mathbf{3 a}, \mathbf{4 a}-\mathbf{4} \mathbf{f}$ are presented below, and in Tables 1-4, and in the Supplementary Materials.

3.5.1. 2'-Hydroxy-5'-methylchalcone 3-O- $\beta$-D-(4'-O-methyl)-glucopyranoside (3a)

$\mathrm{C}_{23} \mathrm{H}_{26} \mathrm{O}_{8}, \mathrm{M}_{\mathrm{W}}=430.45,[\mathrm{M}-\mathrm{H}]^{-} 429.1574 ;{ }^{1} \mathrm{H}-\mathrm{NMR}$, see Table $1,{ }^{13} \mathrm{C}-\mathrm{NMR}$, see Table 2.

3.5.2. 4'-Hydroxy-6-methylflavanone 3'-O- $\beta$-D-(4" -O-methyl)-glucopyranoside (4a)

$\mathrm{C}_{23} \mathrm{H}_{26} \mathrm{O}_{9}, \mathrm{M}_{\mathrm{w}}=446.45,[\mathrm{M}-\mathrm{H}]^{-}$445.1463; $[\alpha]_{D}^{20}=-10.5$ (c = 0.325, acetone); ${ }^{1} \mathrm{H}-\mathrm{NMR}$, see Table 3 , ${ }^{13} \mathrm{C}-\mathrm{NMR}$, see Table 4.

3.5.3. 4'-Hydroxyflavanone 6-methylene-O- $\beta$-D-(4"-O-methyl)-glucopyranoside (4b)

$\mathrm{C}_{22} \mathrm{H}_{24} \mathrm{O}_{9}, \mathrm{M}_{\mathrm{w}}=446.45,[\mathrm{M}-\mathrm{H}]^{-} 445.1549 ;[\alpha]_{D}^{20}=-6.1$ (c=0.365, acetone); ${ }^{1} \mathrm{H}-\mathrm{NMR}$, see Table 3, ${ }^{13} \mathrm{C}-\mathrm{NMR}$, see Table 4.

3.5.4. 6-Hydroxymethylflavanone 3'-O- $\beta$-D-(4"'-O-methyl)-glucopyranoside (4c)

$\mathrm{C}_{22} \mathrm{H}_{24} \mathrm{O}_{9}, \mathrm{M}_{\mathrm{w}}=446.45,[\mathrm{M}-\mathrm{H}]^{-} 445.1506 ;[\alpha]_{D}^{20}=9.1$ (c = 0.175, acetone); ${ }^{1} \mathrm{H}-\mathrm{NMR}$, see Table 3, ${ }^{13} \mathrm{C}-\mathrm{NMR}$, see Table 4. 
3.5.5. 4'-Hydroxy-6-hydroxymethylflavanone 3'-O- $\beta$-D-(4'-O-methyl)-glucopyranoside (4d)

$\mathrm{C}_{22} \mathrm{H}_{24} \mathrm{O}_{10}, \mathrm{M}_{\mathrm{w}}=462.45,[\mathrm{M}-\mathrm{H}]^{-}$461.1418; $[\alpha]_{D}^{20}=54.3$ (c=0.390, acetone); ${ }^{1} \mathrm{H}-\mathrm{NMR}$, see Table 3, ${ }^{13} \mathrm{C}-\mathrm{NMR}$, see Table 4.

3.5.6. 6-Methylflavanone 4'-O- $\beta$-D-(4'-O-methyl)-glucopyranoside (4e)

$\mathrm{C}_{23} \mathrm{H}_{26} \mathrm{O}_{8}, \mathrm{M}_{\mathrm{W}}=430.45,[\mathrm{M}-\mathrm{H}]^{-} 429.1532 ;[\alpha]_{D}^{20}=-50.3$ (c= 0.950, acetone); ${ }^{1} \mathrm{H}-\mathrm{NMR}$, see Table 3, ${ }^{13} \mathrm{C}-\mathrm{NMR}$, see Table 4.

3.5.7. 2-Phenyl-6-methylchromane 4-O- $\beta$-D-(4"-O-methyl)-glucopyranoside (4f)

$\mathrm{C}_{23} \mathrm{H}_{28} \mathrm{O}_{7}, \mathrm{M}_{\mathrm{W}}=416.46,[\mathrm{M}-\mathrm{H}]^{-} 415.1776$ (adduct $[\mathrm{M}+46-\mathrm{H}]^{-}\left[\mathrm{M}+\mathrm{HCOO}^{-} 461.1814\right.$ [57]); $[\alpha]_{\mathrm{D}}^{20}=-25.3(\mathrm{c}=0.390$, acetone $) ;{ }^{1} \mathrm{H}-\mathrm{NMR}$, see Table $3,{ }^{13} \mathrm{C}-\mathrm{NMR}$, see Table 4.

\section{Conclusions}

In this paper we present the results of the glycosylation of a flavanone and chalcone with methyl moiety in entomopathogenic filamentous fungi cultures. The strain B. bassiana $\mathrm{KCH} \mathrm{J1.5} \mathrm{was}$ able to hydroxylate methyl moiety at C-6 of 6-methylflavanone and also to attach to the glycosyl moiety at this site. These microbial transformations have not yet been described in the scientific literature. Moreover, B. bassiana $\mathrm{KCH} \mathrm{J1.5} \mathrm{glycosylated} \mathrm{2'-hydroxyl-5'-methylchalcone} \mathrm{at} \mathrm{C-3} \mathrm{and}$ 6-methylflavanone at $\mathrm{C}-3^{\prime}$. The B. bassiana $\mathrm{KCH} \mathrm{J1.5} \mathrm{enzymatic} \mathrm{system} \mathrm{also} \mathrm{catalyzed} \mathrm{hydroxylation}$ of the flavanone skeleton at C-4'. The second utilized strain-I. fumosorosea $\mathrm{KCH} \mathrm{J2-glycosylated}$ $2^{\prime}$-hydroxyl-5'-methylchalcone at C-3 and 6-methylflavanone at C-4' and C-4. It can be assumed that attachment of the glycosyl moiety at $\mathrm{C}-4$ was preceded by the carbonyl group reduction. This strain was not able to hydroxylate the methyl moiety. All biotransformation products have not been previously described in the scientific literature and may be used in studies assessing their biological activity and bioavailability.

Supplementary Materials: The Supplementary Materials are available online: http://www.mdpi.com/2073-4344/ 10/10/1148/s1.

Author Contributions: Conceptualization, A.K.-Ł. and E.K.-S.; methodology, A.K.-Ł., E.K.-S. and M.D.; validation, A.K.-Ł.; formal analysis, A.K.-Ł., E.K.-S., M.D. and T.J.; investigation, A.K.-Ł.; resources, E.K.-S.; data curation, A.K.-Ł. and E.K.-S.; writing-original draft preparation, A.K.-Ł.; writing-review and editing, A.K.-Ł., E.K.-S. and M.D.; visualization, A.K.-Ł.; supervision, E.K.-S.; project administration, A.K.-Ł. and E.K.-S.; funding acquisition, A.K.-Ł. and E.K.-S. All authors have read and agreed to the published version of the manuscript.

Funding: This research received no external funding.

Acknowledgments: The research is financed/co-financed under the Leading Research Groups support project from the subsidy increased for the period 2020-2025 in the amount of $2 \%$ of the subsidy referred to Art. 387 (3) of the Law of 20 July 2018 on Higher Education and Science, obtained in 2019.

Conflicts of Interest: The authors declare no conflict of interest.

\section{References}

1. Koirala, N.; Thuan, N.H.; Ghimire, G.P.; Thang, D.V.; Sohng, J.K. Methylation of flavonoids: Chemical structures, bioactivities, progress and perspectives for biotechnological production. Enzym. Microb. Technol. 2016, 86, 103-116. [CrossRef] [PubMed]

2. Raffa, D.; Maggio, B.; Raimondi, M.V.; Plescia, F.; Daidone, G. Recent discoveries of anticancer flavonoids. Eur. J. Med. Chem. 2017, 142, 213-228. [CrossRef] [PubMed]

3. Wang, T.Y.; Li, Q.; Bi, K. Bioactive flavonoids in medicinal plants: Structure, activity and biological fate. Asian J. Pharm. Sci. 2018, 13, 12-23. [CrossRef] [PubMed]

4. Vogiatzoglou, A.; Mulligan, A.A.; Lentjes, M.A.H.; Luben, R.N.; Spencer, J.P.E.; Schroeter, H.; Khaw, K.T.; Kuhnle, G.G.C. Flavonoid intake in European adults (18 to 64 years). PLoS ONE 2015, 10, e0128132. [CrossRef] [PubMed] 
5. Kostrzewa-Susłow, E.; Dymarska, M.; Białońska, A.; Janeczko, T. Enantioselective conversion of certain derivatives of 6-hydroxyflavanone. J. Mol. Catal. B Enzym. 2014, 102, 59-65. [CrossRef]

6. Gullón, B.; Lú-Chau, T.A.; Moreira, M.T.; Lema, J.M.; Eibes, G. Rutin: A review on extraction, identification and purification methods, biological activities and approaches to enhance its bioavailability. Trends Food Sci. Technol. 2017, 67, 220-235. [CrossRef]

7. Wen, L.; Jiang, Y.; Yang, J.; Zhao, Y.; Tian, M.; Yang, B. Structure, bioactivity, and synthesis of methylated flavonoids. Ann. N. Y. Acad. Sci. 2017, 1398, 120-129. [CrossRef]

8. Wang, X. Structure, mechanism and engineering of plant natural product glycosyltransferases. FEBS Lett. 2009, 583, 3303-3309. [CrossRef]

9. Plaza, M.; Pozzo, T.; Liu, J.; Ara, K.Z.G.; Turner, C.; Nordberg Karlsson, E. Substituent effects on in vitro antioxidizing properties, stability, and solubility in flavonoids. J. Agric. Food Chem. 2014, 62, 3321-3333. [CrossRef]

10. Thilakarathna, S.H.; Rupasinghe, V.H.P. Flavonoid bioavailability and attempts for bioavailability enhancement. Nutrients 2013, 5, 3367-3387. [CrossRef]

11. Xiao, J.; Muzashvili, T.S.; Georgiev, M.I. Advances in the biotechnological glycosylation of valuable flavonoids. Biotechnol. Adv. 2014, 32, 1145-1156. [CrossRef] [PubMed]

12. Dymarska, M.; Grzeszczuk, J.; Urbaniak, M.; Janeczko, T.; Pląskowska, E.; Stępień, Ł.; Kostrzewa-Susłow, E. Glycosylation of 6-methylflavone by the strain Isaria fumosorosea KCH J2. PLoS ONE 2017, 12, e0184885. [CrossRef] [PubMed]

13. Dymarska, M.; Janeczko, T.; Kostrzewa-Susłow, E. Biotransformations of flavones and an isoflavone (daidzein) in cultures of entomopathogenic filamentous fungi. Molecules 2018, 23, 1356. [CrossRef] [PubMed]

14. Dymarska, M.; Janeczko, T.; Kostrzewa-Susłow, E. Glycosylation of 3-hydroxyflavone, 3-methoxyflavone, quercetin and baicalein in fungal cultures of the genus Isaria. Molecules 2018, 23, 2477. [CrossRef]

15. Dymarska, M.; Janeczko, T.; Kostrzewa-Susłow, E. Glycosylation of methoxylated flavonoids in the cultures of Isaria fumosorosea KCH J2. Molecules 2018, 23, 2578. [CrossRef]

16. Dou, F.; Wang, Z.; Li, G.; Dun, B. Microbial transformation of flavonoids by Isaria fumosorosea ACCC 37814. Molecules 2019, 24, 1028. [CrossRef]

17. Hyung Ko, J.; Gyu Kim, B.; Joong-Hoon, A. Glycosylation of flavonoids with a glycosyltransferase from Bacillus cereus. FEMS Microbiol. Lett. 2006, 258, 263-268. [CrossRef]

18. Gurung, R.B.; Kim, E.H.; Oh, T.J.; Sohng, J.K. Enzymatic synthesis of apigenin glucosides by glucosyltransferase (YjiC) from Bacillus licheniformis DSM 13. Mol. Cells 2013, 36, 355-361. [CrossRef]

19. Xie, L.; Zhang, L.; Wang, C.; Wang, X.; Xu, Y.; Yu, H.; Wu, P.; Li, S.; Han, L.; Gunatilaka, A.A.L.; et al. Methylglucosylation of aromatic amino and phenolic moieties of drug-like biosynthons by combinatorial biosynthesis. Proc. Natl. Acad. Sci. USA 2018, 115, E4980-E4989. [CrossRef]

20. Xie, L.; Zhang, L.; Bai, J.; Yue, Q.; Zhang, M.; Li, J.; Wang, C.; Xu, Y. Methylglucosylation of phenolic compounds by fungal glycosyltransferase-methyltransferase functional modules. J. Agric. Food Chem. 2019, 67, 8573-8580. [CrossRef]

21. Kostrzewa-Susłow, E.; Dymarska, M.; Janeczko, T. Microbial transformations of 3-methoxyflavone by strains of Aspergillus niger. Pol. J. Microbiol. 2014, 63, 111-114. [CrossRef] [PubMed]

22. Wen, X.; Walle, T. Methylated flavonoids have greatly improved intestinal absorption and metabolic stability. Drug Metab. Dispos. 2006, 34, 1786-1792. [CrossRef] [PubMed]

23. Ye, C.L.; Lu, Y.H.; Wei, D.Z. Flavonoids from Cleistocalyx operculatus. Phytochemistry 2004, 65, $445-447$. [CrossRef]

24. Ye, C.L.; Liu, Y.; Wei, D.Z. Antioxidant and anticancer activity of $3^{\prime}$-formyl-4' $6^{\prime} 6^{\prime}$-dihydroxy-2'-methoxy-5' -methylchalcone and (2S)-8-formyl-5-hydroxy-7-methoxy-6-methylflavanone. J. Pharm. Pharm. 2007, 59, 553-559. [CrossRef] [PubMed]

25. Dao, T.T.; Tung, B.T.; Nguyen, P.H.; Thuong, P.T.; Yoo, S.S.; Kim, E.H.; Kim, S.K.; Oh, W.K. C-methylated flavonoids from Cleistocalyx operculatus and their inhibitory effects on novel influenza A(H1N1) neuraminidase. J. Nat. Prod. 2010, 73, 1636-1642. [CrossRef]

26. Chen, W.Q.; Song, Z.J.; Xu, H.H. A new antifungal and cytotoxic C-methylated flavone glycoside from Picea neoveitchii. Bioorg. Med. Chem. Lett. 2012, 22, 5819-5822. [CrossRef]

27. Nobakht, M.; Grkovic, T.; Trueman, S.J.; Wallace, H.M.; Katouli, M.; Quinn, R.J.; Brooks, P.R. Chemical constituents of kino extract from Corymbia torelliana. Molecules 2014, 19, 17862-17871. [CrossRef] 
28. Nobakht, M.; Trueman, S.J.; Wallace, H.M.; Brooks, P.R.; Streeter, K.J.; Katouli, M. Antibacterial properties of flavonoids from kino of the eucalypt tree, Corymbia torelliana. Plants 2017, 6, 39. [CrossRef]

29. Salmazzo, G.R.; Verdan, M.H.; Silva, F.; Cicarelli, R.M.; da Silva Mota, J.; Salvador, M.J.; de Carvalho, J.E.; Cardoso, C.A.L. Chemical composition and antiproliferative, antioxidant and trypanocidal activities of the fruits from Campomanesia xanthocarpa (Mart.) O. Berg (Myrtaceae). Nat. Prod. Res. 2019, 1-5. [CrossRef]

30. Hall, B.J.; Chebib, M.; Hanrahan, J.R.; Johnston, G.A.R. 6-Methylflavanone, a more efficacious positive allosteric modulator of $\gamma$-aminobutyric acid (GABA) action at human recombinant $\alpha 2 \beta 2 \gamma 2 \mathrm{~L}$ than at $\alpha 1 \beta 2 \gamma 2 \mathrm{~L}$ and $\alpha 1 \beta 2$ GABAA receptors expressed in Xenopus oocytes. Eur. J. Pharm. 2006, 512, 97-104. [CrossRef]

31. Boomsma, J.J.; Jensen, A.B.; Meyling, N.V.; Eilenberg, J. Evolutionary interaction networks of insect pathogenic fungi. Annu. Rev. Entomol. 2014, 59, 467-485. [CrossRef] [PubMed]

32. Valero-Jiménez, C.A.; Wiegers, H.; Zwaan, B.J.; Koenraadt, C.J.M.; van Kan, J.A.L. Genes involved in virulence of the entomopathogenic fungus Beauveria bassiana. J. Invertebr. Pathol. 2016, 133, 41-49. [CrossRef] [PubMed]

33. Mascarin, G.M.; Jaronski, S.T. The production and uses of Beauveria bassiana as a microbial insecticide. World J. Microbiol. Biotechnol. 2016, 32, 177. [CrossRef]

34. Cito, A.; Barzanti, G.P.; Strangi, A.; Francardi, V.; Zanfini, A.; Dreassi, E. Cuticle-degrading proteases and toxins as virulence markers of Beauveria bassiana (Balsamo) Vuillemin. J. Basic Microbiol. 2016, 56, 941-948. [CrossRef] [PubMed]

35. Xiao, G.; Ying, S.H.; Zheng, P.; Wang, Z.L.; Zhang, S.; Xie, X.Q.; Shang, Y.; St. Leger, R.J.; Zhao, G.P.; Wang, C.; et al. Genomic perspectives on the evolution of fungal entomopathogenicity in Beauveria bassiana. Sci. Rep. 2012, 2, 483. [CrossRef]

36. Chen, J.; Lai, Y.; Wang, L.; Zhai, S.; Zou, G.; Zhou, Z.; Cui, C.; Wang, S. CRISPR/Cas9-mediated efficient genome editing via blastospore-based transformation in entomopathogenic fungus Beauveria bassiana. Sci. Rep. 2017, 7, 45763. [CrossRef] [PubMed]

37. Kozłowska, E.; Urbaniak, M.; Hoc, N.; Grzeszczuk, J.; Dymarska, M.; Stępień, Ł.; Pląskowska, E.; Kostrzewa-Susłow, E.; Janeczko, T. Cascade biotransformation of dehydroepiandrosterone (DHEA) by Beauveria species. Sci. Rep. 2018, 8, 13449. [CrossRef] [PubMed]

38. Zimmermann, G. The entomopathogenic fungi Isaria farinosa (formerly Paecilomyces farinosus) and the Isaria fumosorosea species complex (formerly Paecilomyces fumosoroseus): Biology, ecology and use in biological control. Biocontrol Sci. Technol. 2008, 18, 865-901. [CrossRef]

39. Weng, Q.; Zhang, X.; Chen, W.; Hu, Q. Secondary metabolites and the risks of Isaria fumosorosea and Isaria farinosa. Molecules 2019, 24, 664. [CrossRef]

40. Kim, H.J.; Lee, I.S. Microbial metabolism of the prenylated chalcone xanthohumol. J. Nat. Prod. 2006, 69, 1522-1524. [CrossRef]

41. Tronina, T.; Bartmańska, A.; Milczarek, M.; Wietrzyk, J.; Popłoński, J.; Rój, E.; Huszcza, E. Antioxidant and antiproliferative activity of glycosides obtained by biotransformation of xanthohumol. Bioorg. Med. Chem. Lett. 2013, 23, 1957-1960. [CrossRef] [PubMed]

42. Huszcza, E.; Bartmańska, A.; Tronina, T. Glycosylation of xanthohumol by fungi. Z. Nat. C J. Biosci. 2008, 63, 557-560. [CrossRef] [PubMed]

43. Hofer, B. Recent developments in the enzymatic O-glycosylation of flavonoids. Appl. Microbiol. Biotechnol. 2016, 100, 4269-4281. [CrossRef] [PubMed]

44. Júnior, G.M.V.; Sousa, C.M.D.M.; Cavalheiro, A.J.; Lago, J.H.G.; Chaves, M.H. Phenolic derivatives from fruits of Dipteryx lacunifera Ducke and evaluation of their antiradical activities. Helv. Chim. Acta 2008, 91, 2159-2167. [CrossRef]

45. Moon, B.H.; Lee, Y.; Ahn, J.H.; Lim, Y. Complete assignment of 1H and 13C NMR data of dihydroxyflavone derivatives. Magn. Reson. Chem. 2006, 44, 99-101. [CrossRef]

46. Park, Y.; Moon, B.H.; Lee, Y.; Yoon, Y.; Ahn, J.H.; Lim, Y. 1H and 13C-NMR data of hydroxyflavone derivatives. Magn. Reson. Chem. 2007, 45, 488-495. [CrossRef]

47. Cuca-Suárez, L.; Monache, F. 6-C-formyl and 6-C-hydroxymethyl flavonoides from Petiveria Alliacea. Phytochemistry 1992, 31, 2481-2482. [CrossRef]

48. Sordon, S.; Popłoński, J.; Huszcza, E. Microbial glycosylation of flavonoids. Pol. J. Microbiol. 2016, 65, 137-151. [CrossRef]

49. Sordon, S.; Popłoński, J.; Tronina, T.; Huszcza, E. Regioselective O-glycosylation of flavonoids by fungi Beauveria bassiana, Absidia coerulea and Absidia glauca. Bioorg. Chem. 2019, 93, 102750. [CrossRef] 
50. Silva, A.M.S.; Tavares, H.R.; Barros, A.I.N.R.A.; Cavaleiro, J.A.S. NMR and structural and conformational features of 2'-hydroxychalcones and flavones. Spectrosc. Lett. 1997, 30, 1655-1667. [CrossRef]

51. Yadav, N.; Dixit, S.K.; Bhattacharya, A.; Mishra, L.C.; Sharma, M.; Awasthi, S.K.; Bhasin, V.K. Potent antimalarial activity of newly synthesized substituted chalcone analogs in vitro. Chem. Biol. Drug Des. 2012, 80, 340-347. [CrossRef] [PubMed]

52. Janeczko, T.; Gładkowski, W.; Kostrzewa-Susłow, E. Microbial transformations of chalcones to produce food sweetener derivatives. J. Mol. Catal. B Enzym. 2013, 98, 55-61. [CrossRef]

53. Palko-Łabuz, A.; Kostrzewa-Susłow, E.; Janeczko, T.; Środa-Pomianek, K.; Poła, A.; Uryga, A.; Michalak, K. Cyclization of flavokawain B reduces its activity against human colon cancer cells. Hum. Exp. Toxicol. 2020, 39, 262-275. [CrossRef] [PubMed]

54. Murti, Y.; Mishra, P. Synthesis and evaluation of flavanones as anticancer agents. Indian J. Pharm. Sci. 2014, 76, 163-166.

55. Gładkowski, W.; Siepka, M.; Janeczko, T.; Kostrzewa-Susłow, E.; Popłoński, J.; Mazur, M.; Żarowska, B.; Łaba, W.; Maciejewska, G.; Wawrzeńczyk, C. Synthesis and antimicrobial activity of methoxy-substituted $\gamma$-Oxa- $\varepsilon$-lactones derived from flavanones. Molecules 2019, 24, 4151. [CrossRef]

56. Mizgier, P.; Kucharska, A.Z.; Sokół-Łętowska, A.; Kolniak-Ostek, J.; Kidoń, M.; Fecka, I. Characterization of phenolic compounds and antioxidant and anti-inflammatory properties of red cabbage and purple carrot extracts. J. Funct. Foods 2016, 21, 133-146. [CrossRef]

57. Li, C.; Zhang, X.; Xue, X.; Zhang, F.; Xu, Q.; Liang, X. Structural characterization of iridoid glucosides by ultra-performance liquid chromatography/electrospray ionization quadrupole time-of-flight tandem mass spectrometry. Rapid Commun. Mass Spectrom. 2008, 22, 1941-1954. [CrossRef]

(C) 2020 by the authors. Licensee MDPI, Basel, Switzerland. This article is an open access article distributed under the terms and conditions of the Creative Commons Attribution (CC BY) license (http://creativecommons.org/licenses/by/4.0/). 